السبك والحبك في معلقة امرئ القيس

\title{
(دراسة نصية)
}

د/أحمد محمد الثوادفي

(الملخص

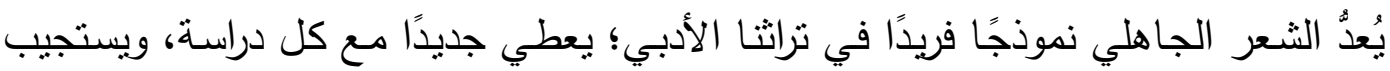
للنظريات الحديثة؛ كما استجاب للنظريـات القديمة، وامرؤ القيس أمير شعراء الجاهليـة؛ وأول الطبقة الأولى في طبقات الثعراء الفحول؛ المقَّم على أصحاب المعلقات.

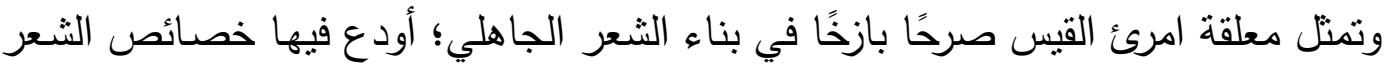

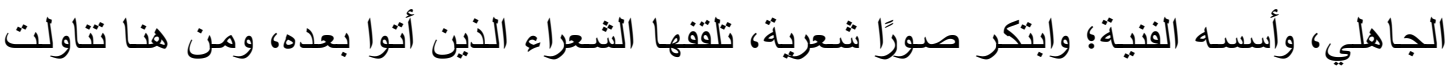
المعلقة أقلام متعددة بالنقد والتحليل.

وتتاولت هذه الدراسة المعلقة من خلال النقد اللساني، مفيدة من منجز نحو النص، أو علم

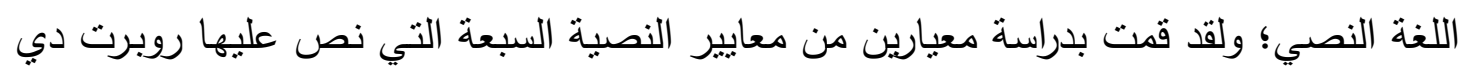

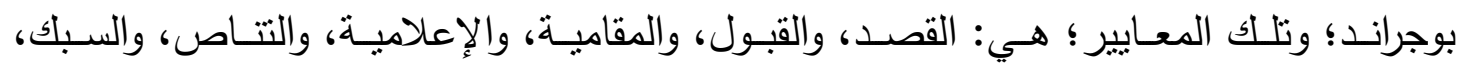
والحبك.

فكان معيارا السبك والحبك؛ مناط البحث؛ حيث إن معيار السبك الذي يُطلق عليه الترابط الرصفي؛ يعمل في ظاهر النص؛ ويحقق الترابط على مستوى السطح، وأثره في التكوين الثعري

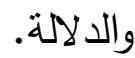

ومن أهم الوسائل التي حققت لنص المعلقة سبكه؛ التكرار بأنواعه: التكرار الدضض، والتكرار

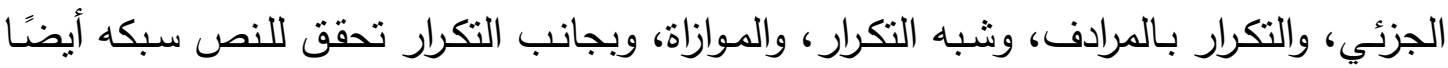
عن طريق التضام، والتعريف والتتكير ، والحذف، والإحالة، والربط. بينما المعيار الثاني الحبك؛ يعمل في عالم النص؛ حيث يتحقق التماسك النصي عن طريق

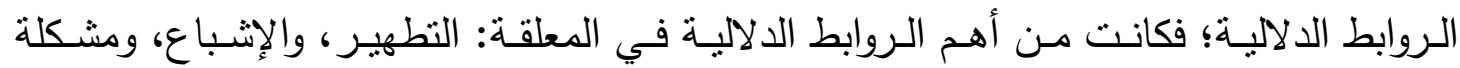

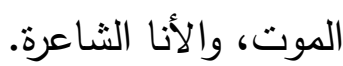




$$
\begin{aligned}
& \text { ومن خلال تطبيق هذين المعيارين؛ اتضح أن الثَاعر قدم نصنًا مترابطًَا مسبوكًا، ومحبوكًا؛ } \\
& \text { ومتماسكًا على مستوى بنية السطح، وبنية العمق. }
\end{aligned}
$$

\section{Abstract}

Pre- Islamic Poetry is a unique example in our literary heritage, revealing new with any study and responding to the modern theories likewise the old ones. Imru' al-Qais is considered as the prince of poets during that era as well as one of the pioneer poets in hanging poems " $\mathrm{Al}$ Mu'allaqat".

Imru' al-Qais' Hanging Poem is regarded as an outstanding construction in Pre- Islamic Poetry in which he placed the characteristics and the technical foundations of Pre- Islamic Poetry. As well, he invented new poetic images. This hanging poem was handled through criticism and analysis.

This study deals with Imru' al-Qais' Hanging Poem through the linguistic criticism method by choosing two of the seven textual standards that were mentioned by Robert De Beaugrande as: intentionality, acceptance, intertextuality, informativity, consistency, cohesion and coherence.

So, this study deals with cohesion and coherence standards. The cohesion criterion is called "collocation" or "the syntax consistency" which achieves its role through dealing with the external text and its effect on the semantical and poetic construction. The cohesion in this poem is achieved through "Reiteration": full and partial reiteration, synonym reiteration and Parallelism. As well, cohesion can be achieved through convergence, ellipsis, substitution and junction.

While the second criterion "coherence" is shown in the textual consistency through the semantical conjunctions such as: Catalysis, Catharsis, death issue and egoism.

Through applying these standards, it was clear that the poet has represented a coherent and consistent text at the external and the internal depth levels of construction. 
وصل الثـعر الجاهلي إلينا ناضجًا، مكتمل الأركان، ومن ثم يمثل الأساس الذي قام

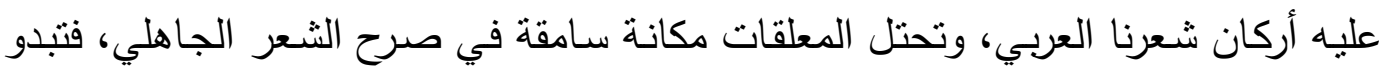
فيها معالم هذا الثعر ، وأصوله، وسماته الفنية.

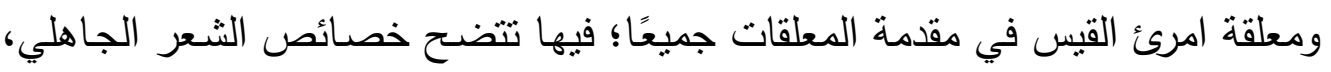
وأسسه الفنية والتعبيرية، وفيها كثير من الصور الفنية المبتكرة؛ التي تلقفها الثعراء من بعده. وامرؤ القيس أمير شعراء الجاهلية؛ ولهذا سلكه ابن سلام الجمحي في الطبقة الأولى في

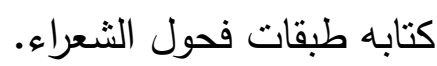

والنص الأدبي مادته اللغة، واللغة لحمته وسداه، ومن هنا يجب أن ينطلق الناقد

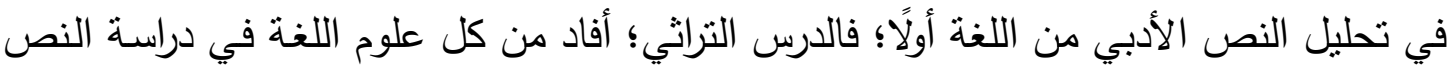

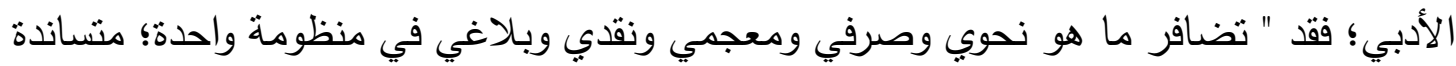

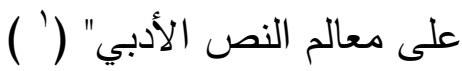
ولم تستمر هذه العلاقة بكثير من القوة والمتانة التي تمتعت بها قرونًا عديدة في تراث العرب

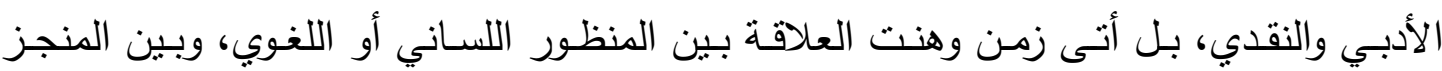
الأدبي؛ مما كان له تأثير سلبي؛ لحق نقد النص ولن الأدبي. وهذه الأثار السلبية؛ دفعت بعض اللسانين والنقاد المعاصرين؛ إلى محاولة إعادة العلاقة بين ما هو نقدي، وبين ما هو لساني؛ فاتخذوا المنهج اللساني مفتاحًا لنق النص. ومن أهم هذه المناهج اللسانية؛ نحو النص، أو علم اللغة النصي، وقد تعدت مهمة هذا العلم نحو الجملة، ونحو ما فوق الجملة، وأصبح هذا العلم ينظر إلى النص بشكل عام، وما يحقق وحدته الكلية؛ فيبحث عن الخيوط التي تحقق نرابط النص وتماسكه، وتجعله نسيجًا محكم البناء. 
ومن ثم يكون النص حدثًا تواصليًّا عند روبرت دي بوجراند، ويلزم لكونه نصًَا أن تتوافر

$$
\text { (القصد - القبول - المقامية - الإعلام - التناص - السبك - الحبك(ب). }
$$

وقد اهتمت البلاغة القديمة، والنقد الأدبي بهذه المعايير، فعناصر السبك عناصر نحوية ومعجميـة، والحبك يتحقق عن طريـق الروابط الدلاليـة، وهذا وثئق الصـلة بقضية اللفظ

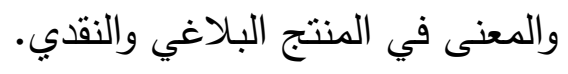

والموقفيـة مرتبطـة بفكرة المقام، وهنـاك إنشارات في النقد القديم إلى منشـئ الخطـاب والمخاطَب، وهذا يرتبط بمعياريْ المقصدية والمقبولية، ويشير معيار الإعلامية إلى ما يجده

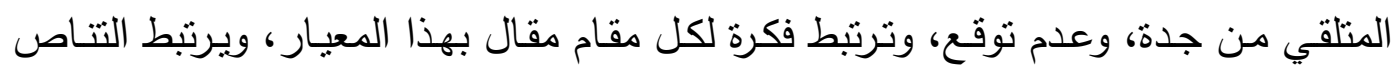

$$
\text { بمصطلحئ التضمين والاقتباس("). }
$$

ومسن هنـا يكون نحو النص، أو علم اللغـة النصـي؛ امتـادًا وتطويرًا لقضـايا البلاغـة

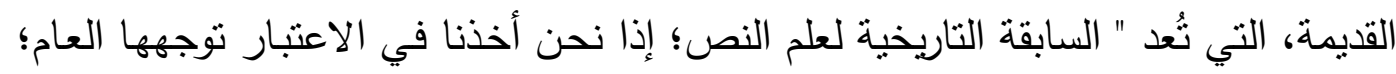

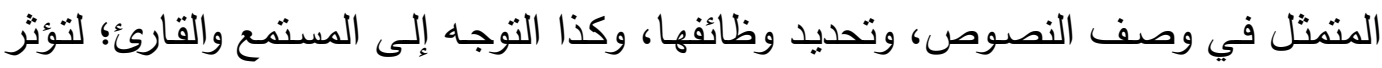

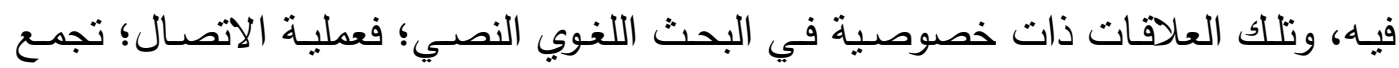
العلاقة بين أطراف الاتصال الأساسية (نص - منتج - منلقٍ)، وكيفيات التفاعل بينها"( أ). لكنَّ هناك فرقًا بين البلاغيين والنقاد القدماء، وبين اللسانيين الدحدثين؛ فقد اعتمدت البلاغة القديمة على نحو الجملة، والاهتمام بالثناهد والمثال. بينما انفتحت اللسانيات الحديثة على آفاق غير محدودة، وتجاوزت نحو الجملة إلى نحو

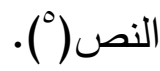

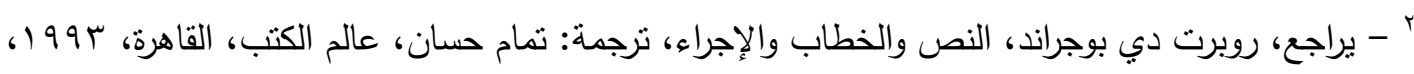
ص r ب (1)، وما بعدها.

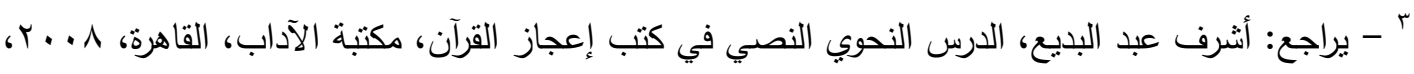
. ؛ - صلاح فضل، بلاغة الخطاب وعلم النص، عالم المعرفة، الكويت، ب99 199، ص ror.

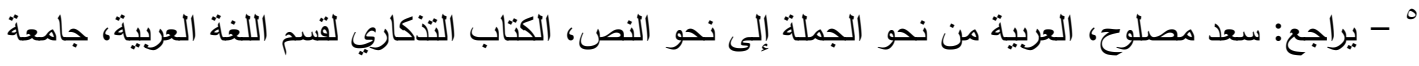

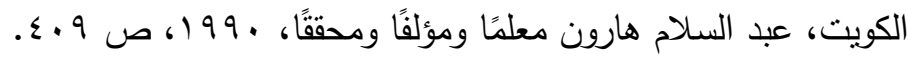


ولأهمية المعلقة، وأهمية هذا المنهج؛ نم اختبار معياريْ السبك والحبك موضوعًا للبحث؛ فالتماسك النصي؛ مرتبط معيارين رئيسين؛ المعيار الأول يُطلق عليه السبك، والمعيار الثاني

$$
\text { يطلق عليه الحبك ("). }
$$

والسبك أقرب إلى ظاهر النص؛ ويرتبط بالنحو، والحبك أقرب إلى الروابط التضمينية،

$$
\text { وهو شديد الارتباط بالدلالة) ('). }
$$

ومعيارا التماسك مـن المعايير التي تحقق للنص نصيته، والنص " يجدر أن يكون

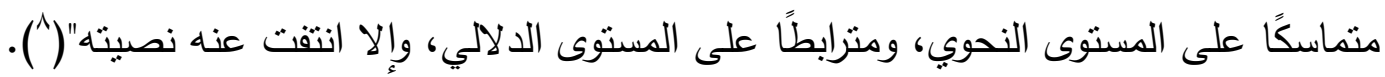
ومهما يكن من أمر ؛ فإن وسائل الحبك روابط دلالية؛ بينما وسائل السبك روابط نحوية؛ ويمكن تتاول هذين المعيارين على النحو الآتي:

أولاً: السبك

مصطلح السبك؛ يُطلق عليه الترابط الرصفي، ومصطلح السبك ورد عند علمائنا القدماء؛

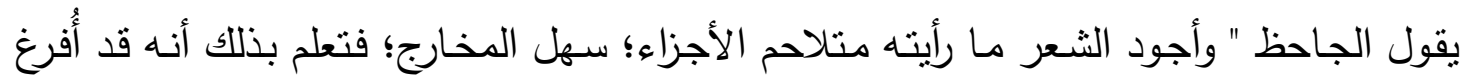

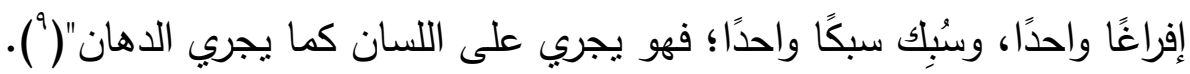
ويذكر عبد القاهر مصطلح السبك في أثناء حديثه عن نزابط الجمل؛ حيث يقول: " إنك ترى

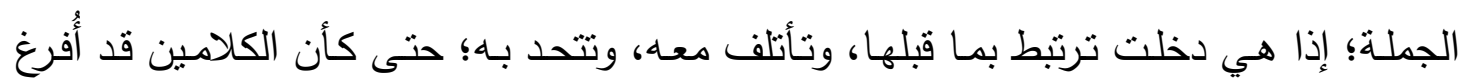
إفراغًا واحدًا؛ وكأن أحدها قد سُبك في الآخر "( ').

" - يراجع: سعد مصلوح، نحو أجرومية للنص الثعري، دراسة في قصيدة جاهلية، مجلة فصول ، مج. ا، ع ال،

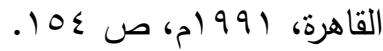

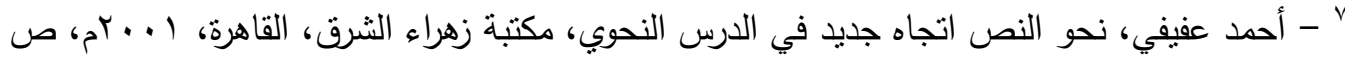
$.1 \cdot r$

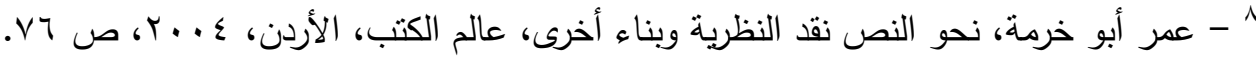

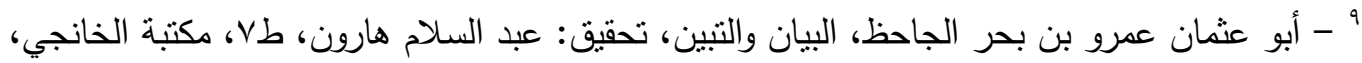

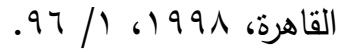

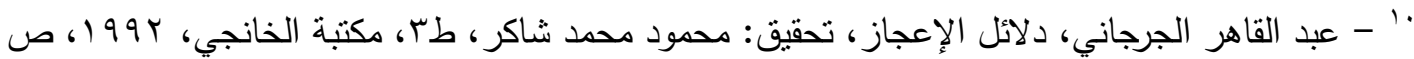


وورد مصطلح السبك عند ابن الأثثر (")، وشيوع مصطلح السبك عند القدماء، لا يعنى أنه

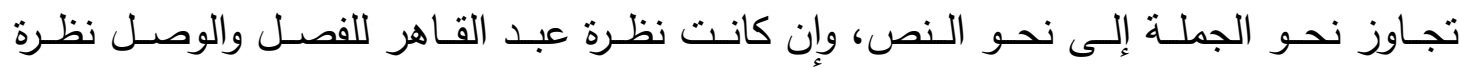

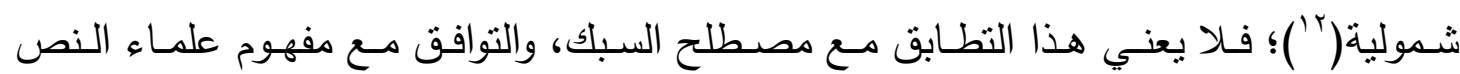
المحدثين لهذا المصطلح.

فالسبك عند المحدثين يختص بالاستمرارية التي تتحقق في ظاهر النص surface text ، "

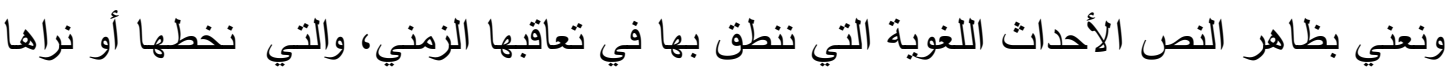

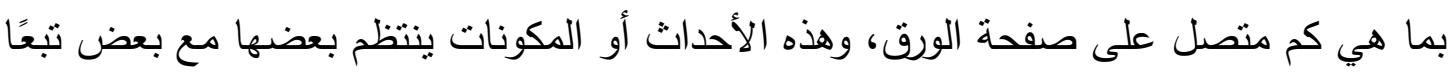

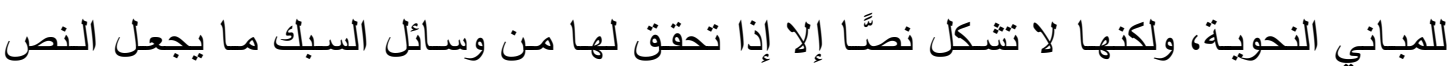
محتفظًا بكينونته واستمراريته، ويجمع هذه الوسائل مصطلح عام هو الاعتماد النحوي"(")"). وتتثثل وسـائل السبك في : التكرار ، والتضـام، والتعريف والتتكير ، والإحالـة، والاستبدال،

$$
\begin{aligned}
& \text { والحذف، وأدوات الربط (') . } \\
& 1 \text { - التكرار: }
\end{aligned}
$$

التكرار من البنى التعبيريـة التي تتولد منها مجموعـة من القيم الأسلوبية المختلفة، وارتبط

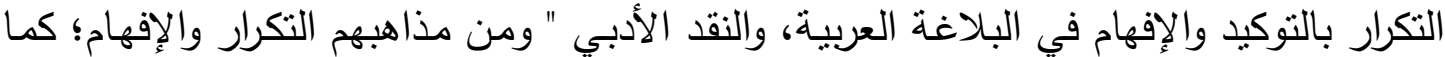
أن من مذاهبهم الاختصار ، وإرادة التخفيف والإيجاز "( الإعة ). ويـرتبط التكرار في النظريـات الحديثة بالحدة؛ فتكرار عنصـر يضـمن تضــاعف الحـدة، والعنصر المكرر أقوى من العنصر المفرد(")'.

"' - يراجع: ضياء الدين بن الأثير الدثل السائر ، تحقيق: أحمد الحوفي، بدوي طبانة ، دار نهضة مصر، داه

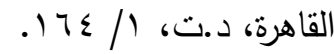

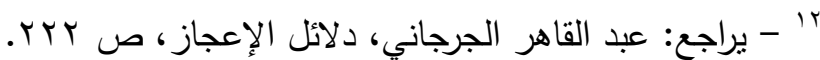

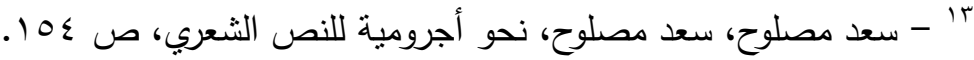

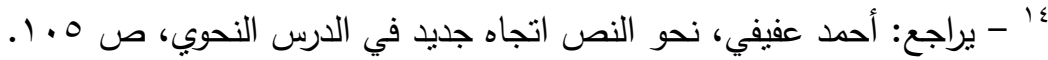
10 r r

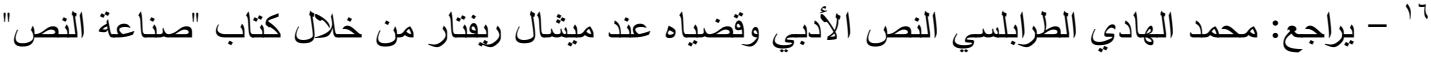

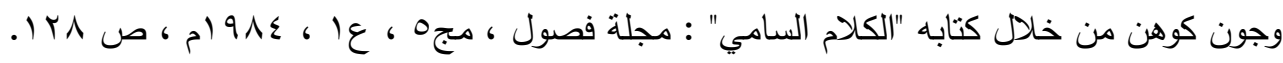




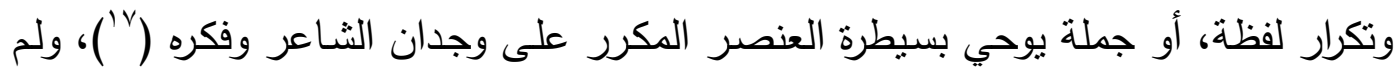
تتوقف مهمة التكرار عند هذا الحد في الإسهام في جماليات النص، بل يضـاف إلى وظائفه

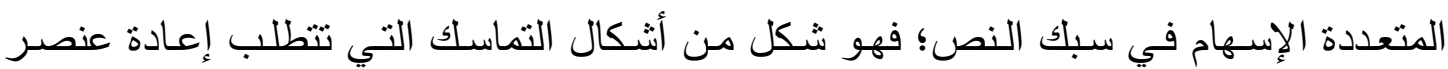

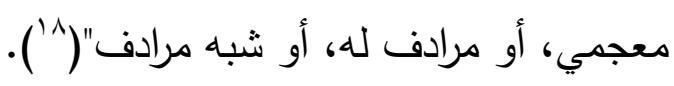
ومن ثم؛ فإن التكرار؛ يهدف إلى تدعيم التماسك النصي؛ عن طريق إعادة عنصر معجمي؛

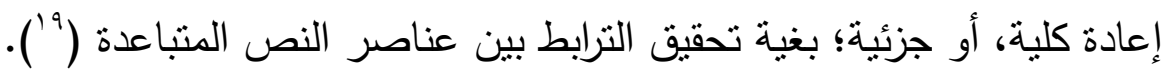
وتتتوع أثنكال التكرار في معلقة امرئ القيس، ونقف على صوره المتعددة في النص الثعري؛ لنتبين أثره في تماسك النص على النحو الآتي: أ-التكرار المحض/ الكلي: يتردد التكرار المحض، أو الكلي في المعلقة على المستوى الأفقي، وعلى المستوى الرأسي؛ ويتردد أيضًا على المستويين الأفقي والرأسي في آنٍ واحد. ومن أمنتة النوع الأول، قوله: - م

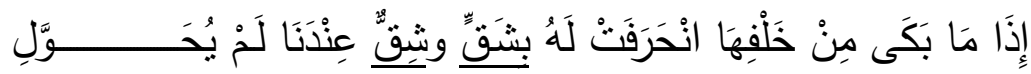

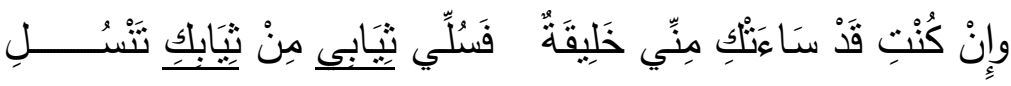

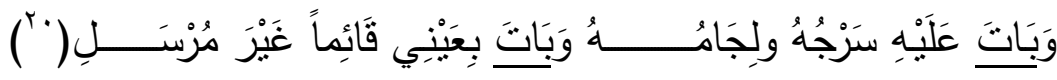
فالتكرار في البيت الأول لمفردة (شق)، ولكن إن كان التكرار لفظة واحدة؛ فإنه ينبه إلى في

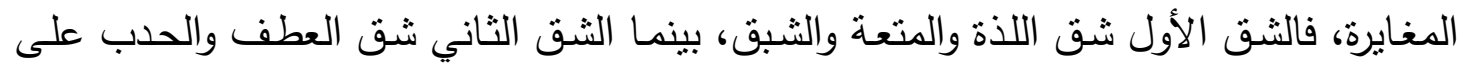

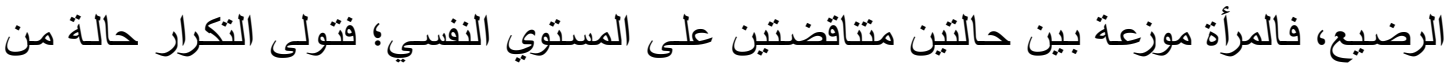
الربط بين الثقين والتخفيف من حالة التشظي على المستوى اللفظي.

"' - يراجع: علي عشري زايد، عن بناء القصيدة العربية الحديثة، طس، مكتبة النصر ، القاهرة، ب991، ص

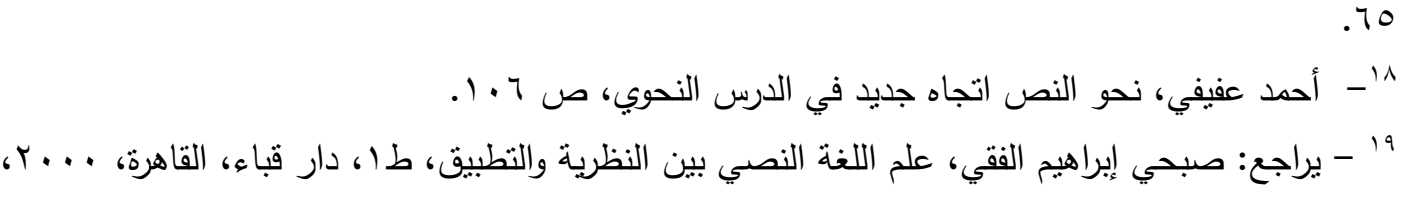
rt/

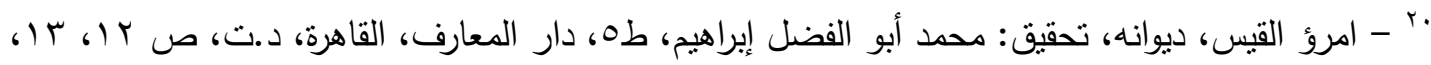


وتكرار الثياب في البيت الثاني؛ يُعد عنصر تجميع على مستوى البيت الثعري؛ فإن كان القرب المكاني يشير إلى تماسلك التعبير ؛ فإنه أيضا يعبر عن تماهي العانشق في المعشوق.

ويتولى التكرار المهمة نفسها في البيت الثالث؛ حيث يقوم بدوره في تماسك البيت، وتماهي

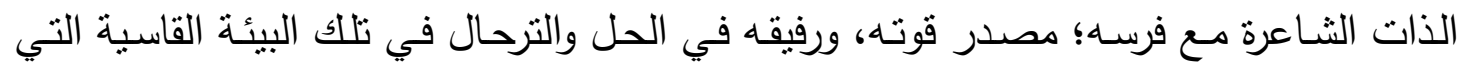

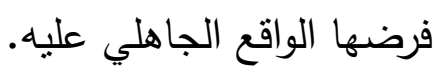
والتكرار على المستوى الرأسي؛ نجده في قول امرئ القيس:

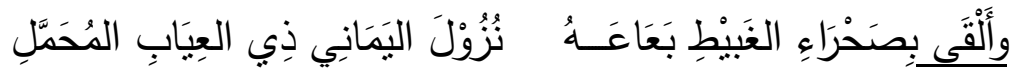

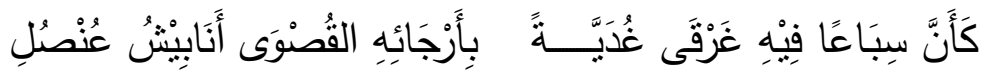

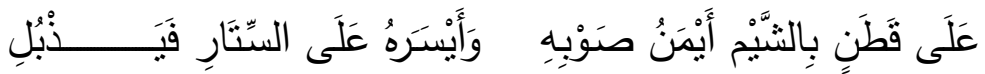

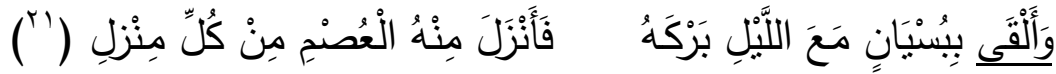

إن تكرار ( ألقى) على المستوى الرأسي أسهم في ترابط مجموعة من الأبيات، حيث إن (

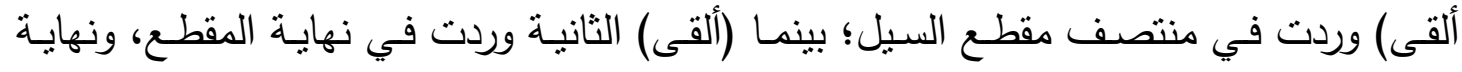
القصيدة، وطرفا التكرار مرنبطان بالسيل، ومن هنا لم يعد التكرار يسهم في تماسك الأبيات التي

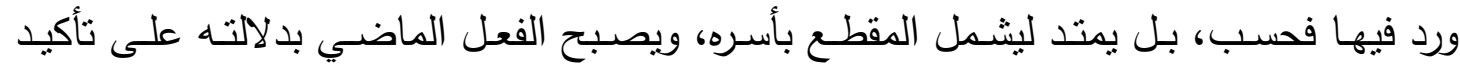

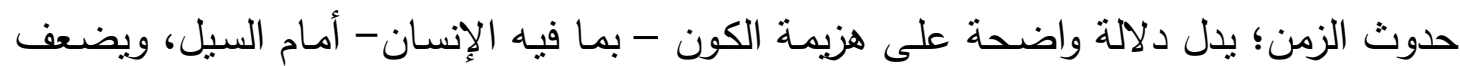
تحت وطأة سطوته.

ويتجلَّى التكرار على المستوي الرأسي أيضًا في مقطع وصف امرؤ القيس الليل؛ يقول:

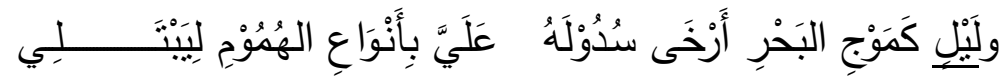

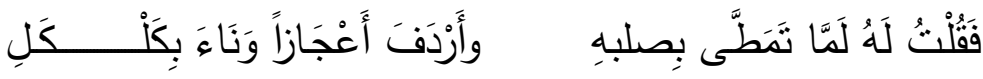

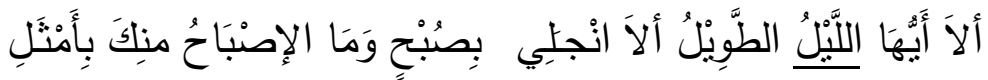

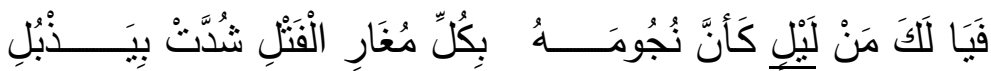

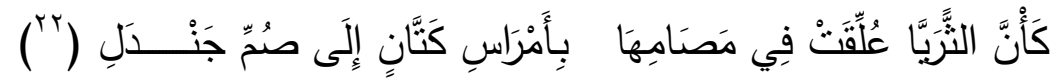


يمثل الليل وسيلة ضغط على الثاعر ؛ كما يُعد مصدر أرق له؛ فقد قُتل أبوه الملك، فليل

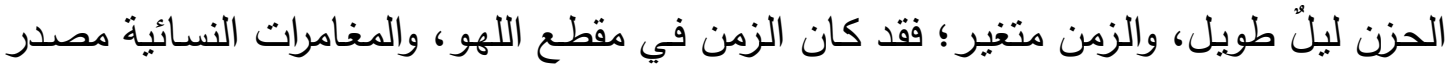

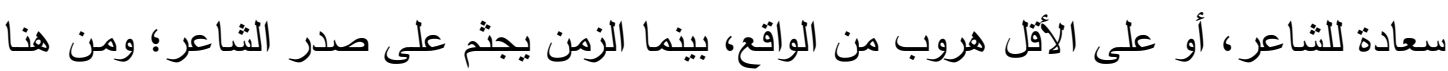

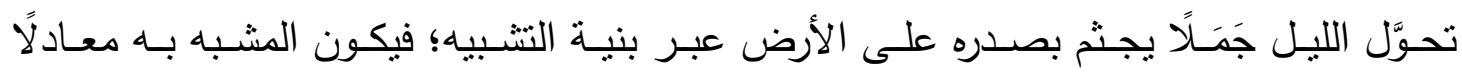

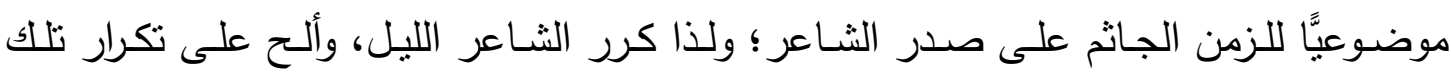

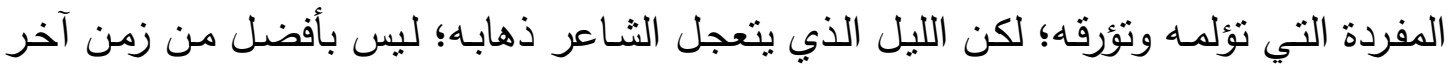

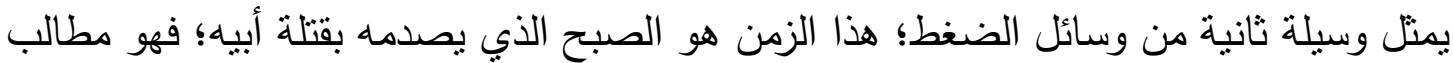

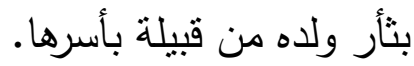

إن كان الزمن أدى وظيفة فنية في ترابط المقطع، وتماسك أبياته في ظاهر النص؛ إلا أنه

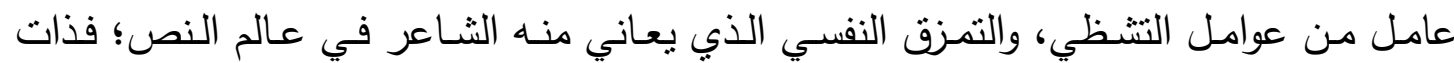
الثناعر لم تعد ذانًا واحدة، بل تحولت إلى عدة ذوات.

والتكرار على المستوى الأفقي والمستوى الرأسي؛ تكثر نماذجه؛ نذكر منها:

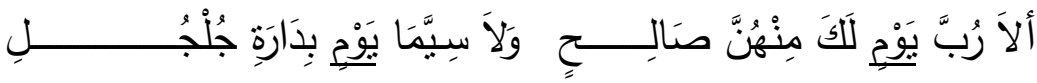

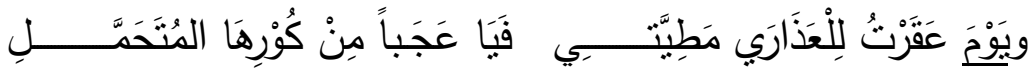

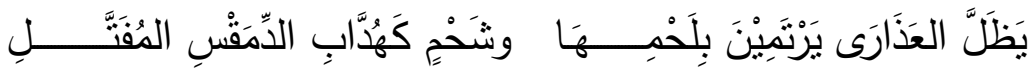

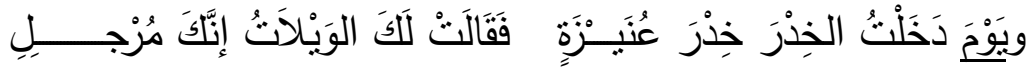

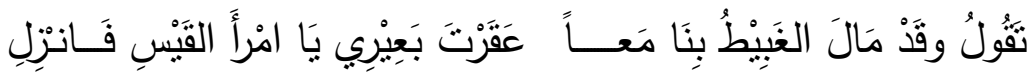

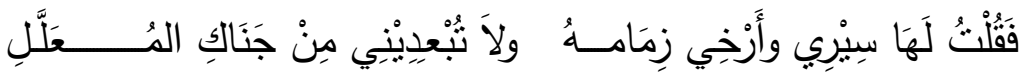

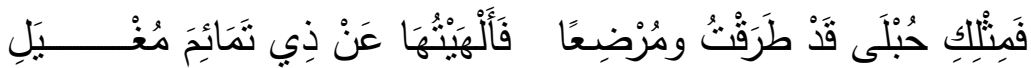

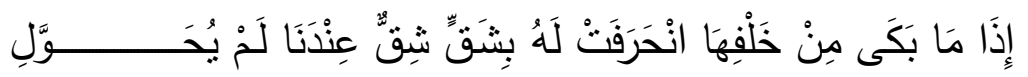

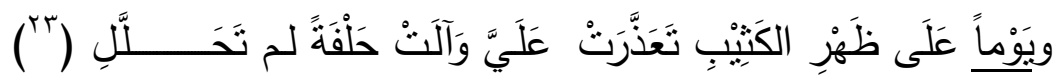




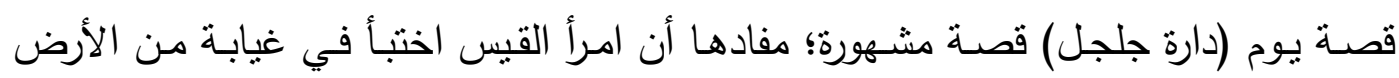

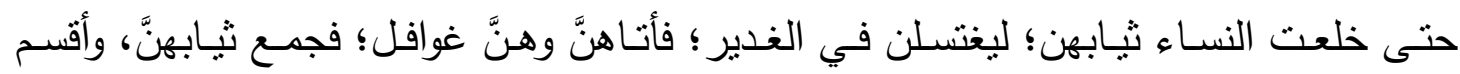

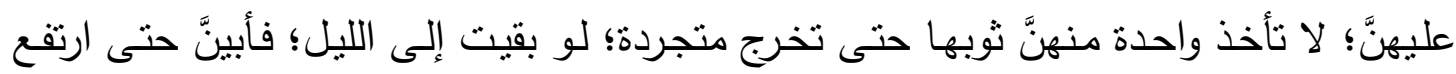

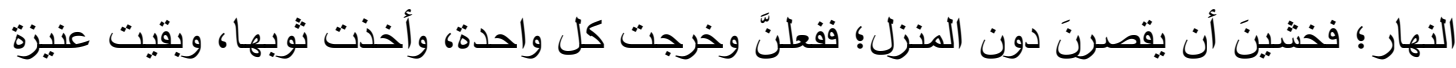

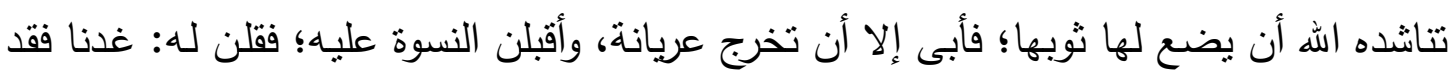

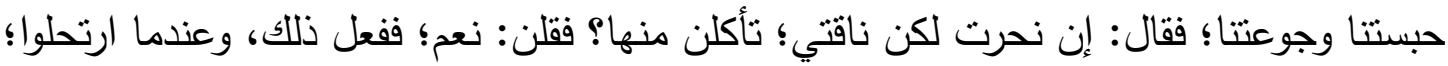

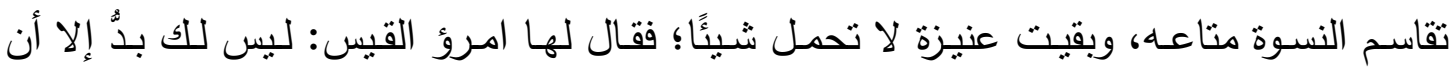
تحمليني معك؛ فحملته على بعيرها؛ فكان يميل إليها ويدخل رأسه في خدرها ويقبلها؛ فإذاذا مال

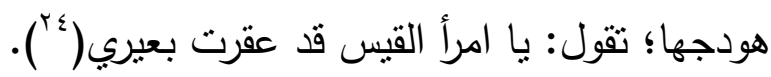

تكرر دال (يوم) خمس مرات، تكرر في البيت الأول على المستوي الأفقي، وتكرر في باقي

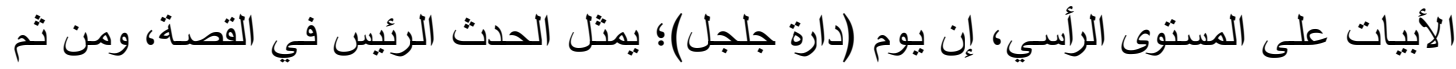

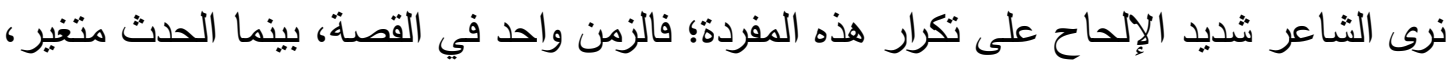

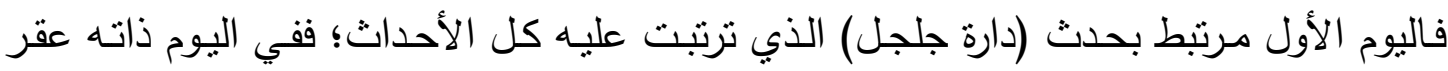
للنساء بعيره، وفي اليوم ذاته أردفته " عنيزة" على بعيرها؛ وأخذ يقبلها، وبعد خمسة الأبه أبيات يعود الاحد

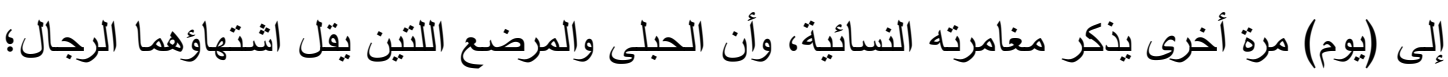

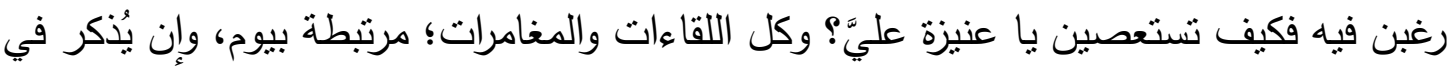

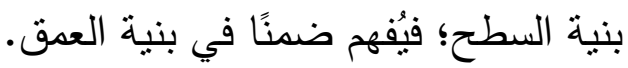

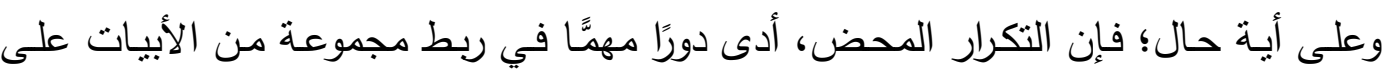

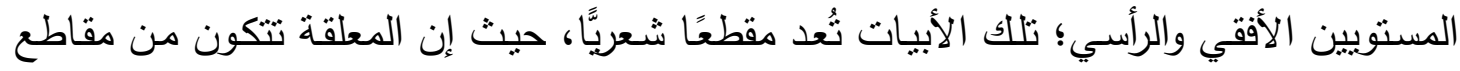

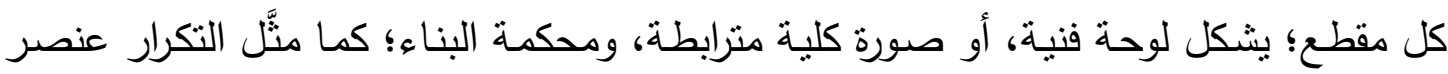

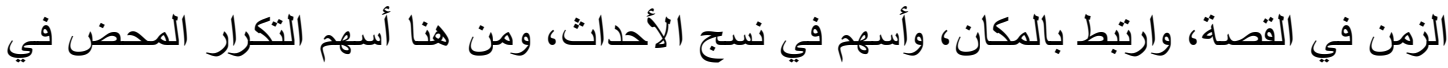

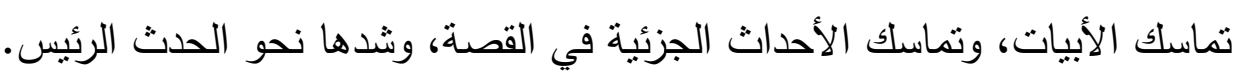

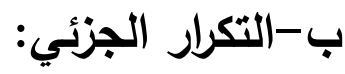

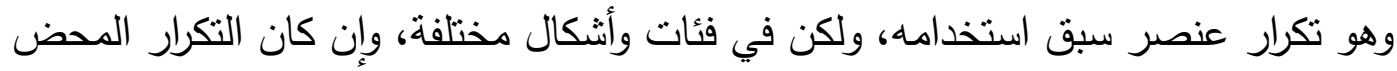

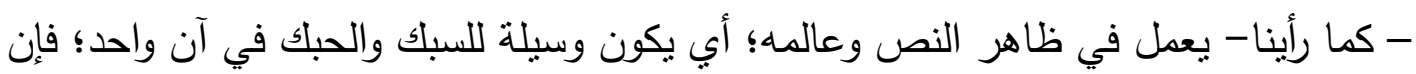
\&

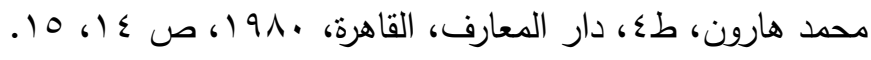


التكرار الجزئي؛ يفعل فعله في ظاهر النص أصالة، وفي عالمه بالتبعية(ب0.). ويبدو التكرار الجزئي واضحًا في اختلاف الصيغة الصرفية؛ فنرى الثناعر يراوح بين صيغة المفرد، وبين صيغة الجمع في قوله:

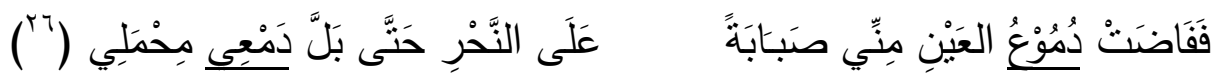
بدأ الثـاعر البيت بإسناد الفيضان إلى المسند إليه الجمع (دموع)، الدال على الكثرة، وغزارة الدموع، فجاء الفاعل الجمع بينه وبين الفعل (فاضت) تتاسب، بينما جاء المفرد (دمع) مناسبًا

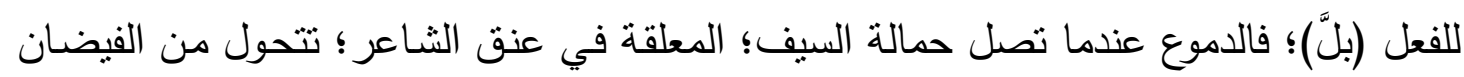
إلى قطرات، والتكرار الجزئي شدَّ شطريْ البيت برباط وثيق، فأدى وظيفة فنية في تماسك البيت. ويـراوح الثـاعر في مشـهد الفرس بـين صـيغتي (الماضـي - المضـارع)، وبين صـيغتيْ (الماضي - صيغة المبالغة)؛ يقول:

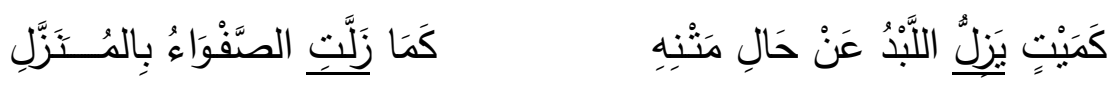

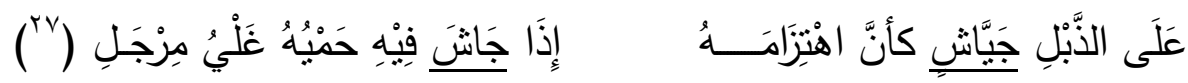

طرفا التكرار في البيت الأول (يزلٌ - زلَّ)، في الثطر الأول يزل اللبد؛ يشير إلى انملاس

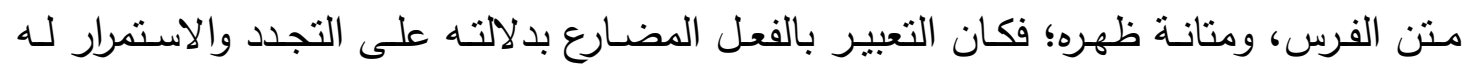

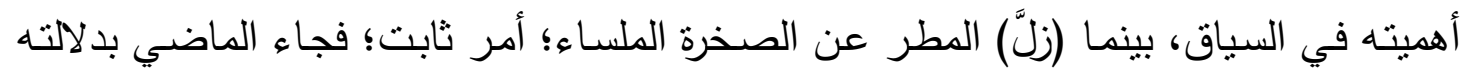
على الثبوت مناسبًا للسياق، بينما صفة الفرس ليست ثابتة؛ فتختلف من فرس إلى آخر آلى ، والتكرار الجزئي ربط طرفي النتبيه التمثيلي في البيت.

والتكرار الجزئي في البيت الثاني؛ مزواجة بين صيغة المبالغة، وصيغة الماضي (جيَّاش -

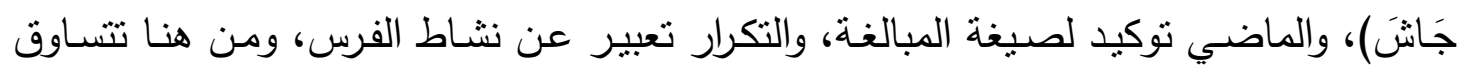

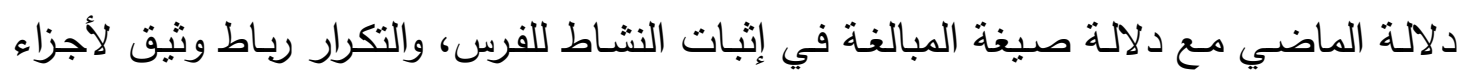


ويمتد التكرار على المستوى الرأسي؛ فيشمل مساحة واسعة في الفضاء الثشعري، من خلال

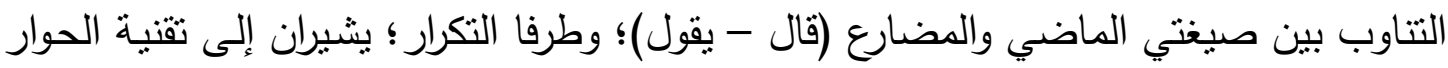

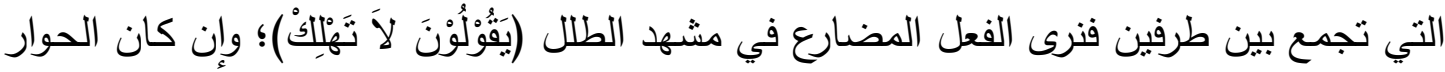

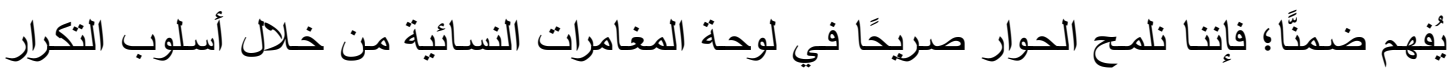

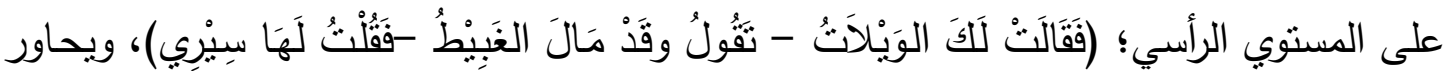

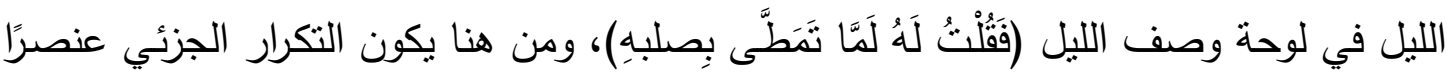
أقرب إلى التجميع من الانتشار .

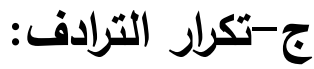

الترادف من الظواهر التعبيرية التي تتردد في اللغة العربية، وتعني هذه الظـاهرة " الألفاظ

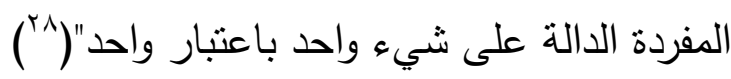
يظهر الترادف على المستوى الرأسي في بعض المواضع؛ نختار مثالين من جملة الأمتلة؛ لتتضح من خلالهما الفكرة؛ حيث يقول امرؤ القيس:

فَهَلْ عِنْدَ رَسنْ دَارِسِ مِنْ مُعَســــوَّلِ

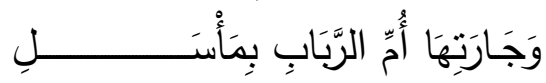

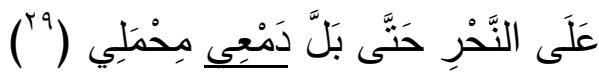

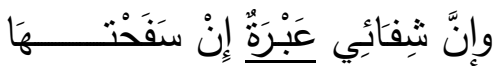

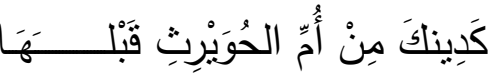

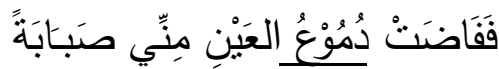

يتجلى تكرار الترادف في البيتين الأول والثالث (عبرة - دموع - دمع)، وهذا التكرار لـه تأثنير

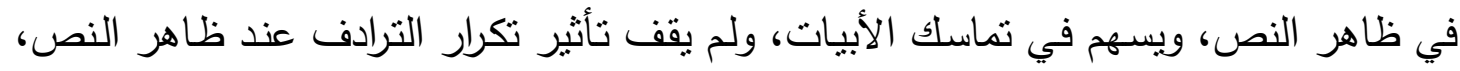

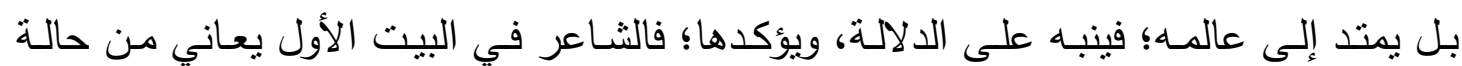

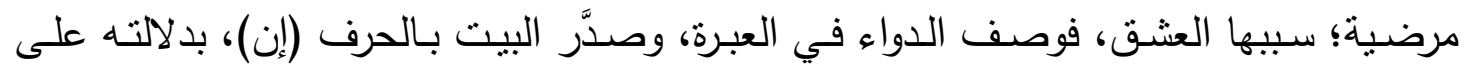
الثك، فقد تستعصي العبرة عليه؛ لكن الثفاء أني في البيت الثالث عن طريق المرادف؛ حيث فاضت الدموع/ الثفاء. أما المثال الثاني؛ ففي قول الثناعر:

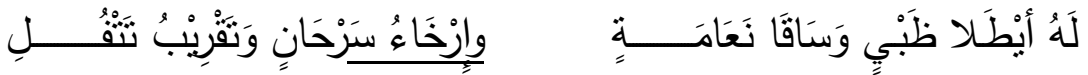
^^^ - جلال الدين السيوطي، المزهر في علوم اللغة، تحقيق، البجاوي، وأبو الفضل، وجاد المولي، دار الكنب

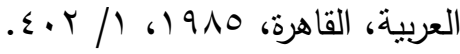

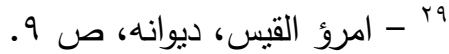




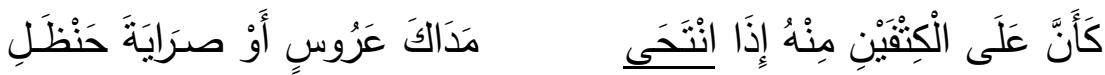

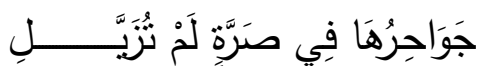

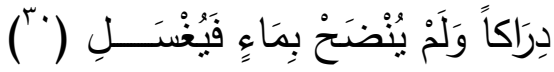

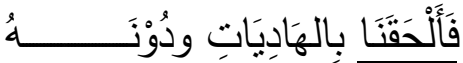

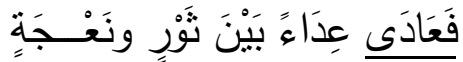

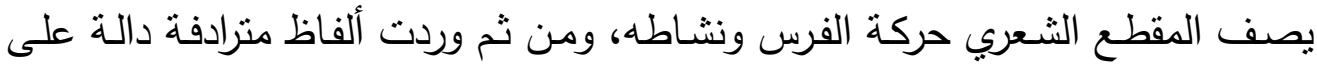

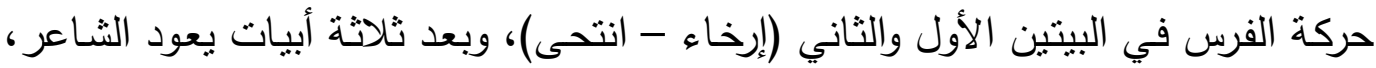
ويذكر لفظين دالين على الحركة (فألحقنا - فعادي).

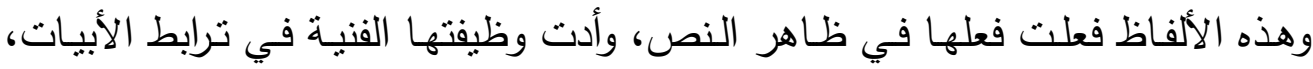

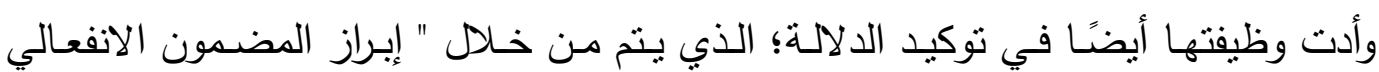

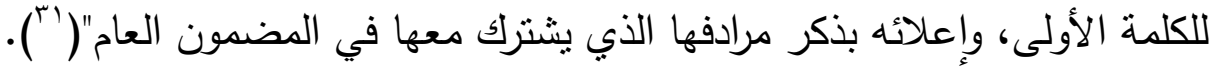
التكرار بالترادف يعمل في ظاهر النص عن طريق تجميع المترادفات؛ يتبعه ترابط دلالي في عالم النص عن طريق تأكيد الدلالة.

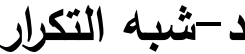

يفتقد شبه التكرار إلى التكرار الدض " ويتحقق شبه التكرار غالبًا على مستوى التشكيل الصوتي، وهو أقرب إلى ما سماه الإمام السكاكي الجناس المحرف بأنواعه: الناقص والمزيل، ثم

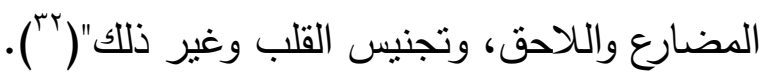
وهذا النوع نجد له أمثلة قليلة جدًا في المعلقة؛ تتمثل في الجناس الناقص في حشو البيت، وفي قافيته؛ في الحشو منل قوله:

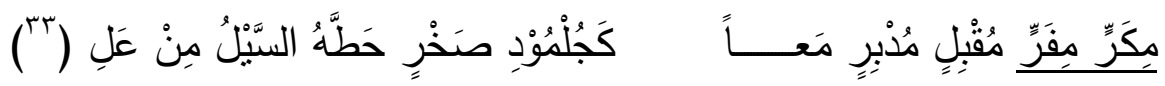
جانس الثناعر بين (مِكَرّ -مِفِرِّر)، والجناس هنا يربط على مستوى الثَكل بين صفتين من

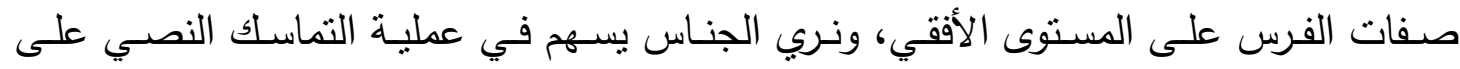
المستوي الرأسي في منطقة القافية؛ مثل (المفصّل - المتفضّّل) - ( معجَّل - مرجَّل)، والتكرار

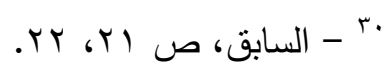

" - محمد العبد، إبداع الدلالة في الثعر الجاهلي مدخل لغوي أسلوبي، طا، دار المعارف، القاهرة، 1911 1، 
الصوتي في القافية عامل من عوامل التماسك والترابط، ويزيد الجناس في القافية ترابط الأبيات

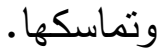

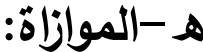

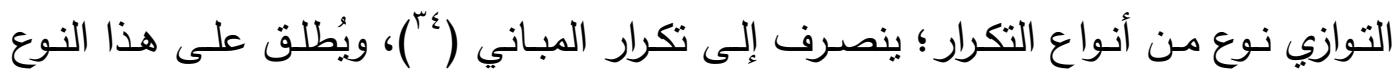

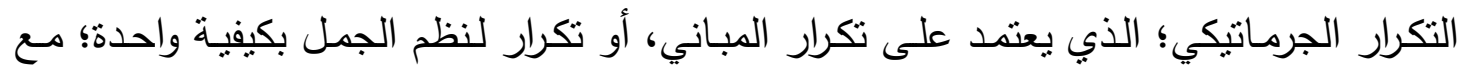

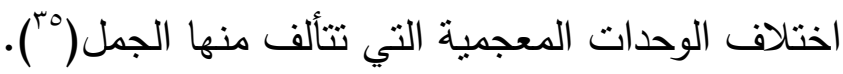

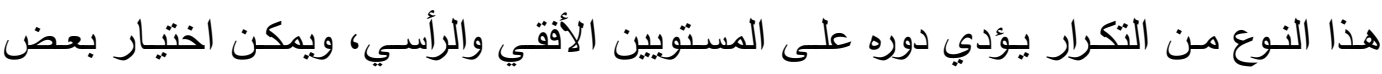
النماذج؛ حتى لا يضيق بنا الدجال، ونرى التوازي على المستوى الأفقي في مطلع المعلقة:

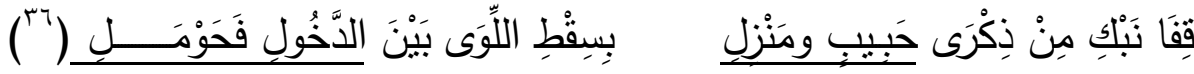

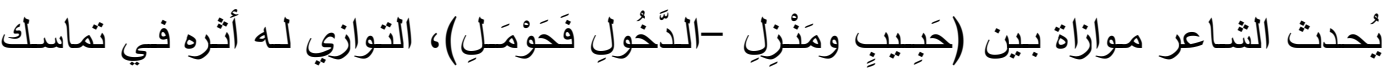
شطري البيت، كما أنه يوفر للمطلع أكبر طاقة موسيقية عن طريق التصريع، والتماثل المكاني؛ حيث إن المتوازيات مثنا (فعولن مفاعلن) في صدر البيت وعجزه. ونماذج الموازاة على المستوى الأفقي متعددة في المعلقة، ونذكر شاهدًا للتوازي على المستوي الرأسي في مشهج وصف الفرس، يقول الثناعر :

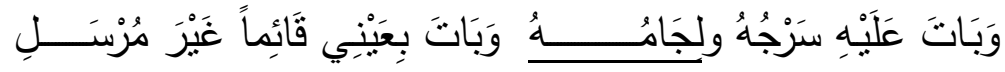

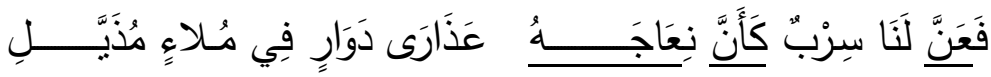

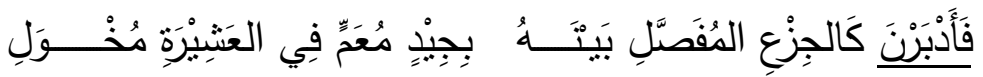

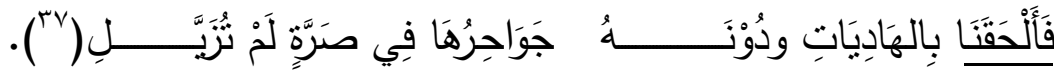

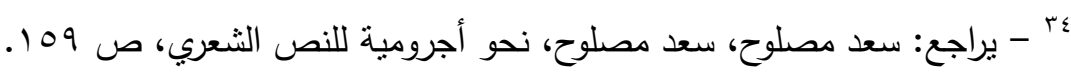

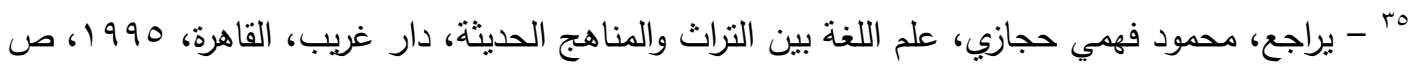
. YT.

$$
\begin{aligned}
& \text { ب" - امرؤ القيس، ديوانه، ص ^. }
\end{aligned}
$$

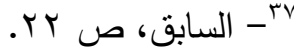




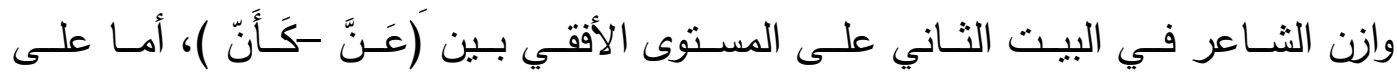
المستوى الرأسـي؛ فنلمح الموازاة على المستوى الرأسي في البيتين الأول والثاني بين (لِجَامُهُهـنعاجه)، والتماسك بين البيتين يحدث عن طريق النوازي، والجناس الناقص بين المتوازيين.

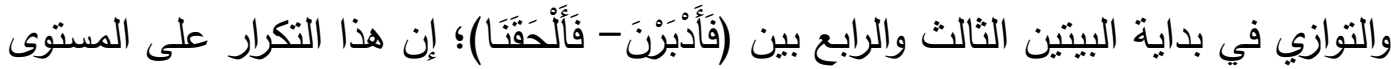

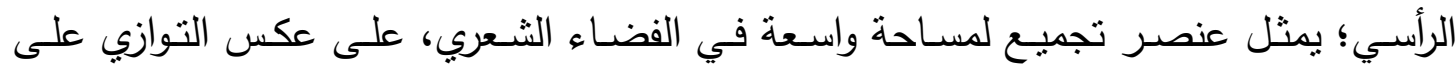
المستوى الأفقي الذي يُحدث التماسك على مستوى البيت.

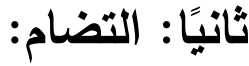

التضام عنصر من عناصر السبك المعجي، ويُعرف بأنه " توارد زوج من الكلمات بالفعل،

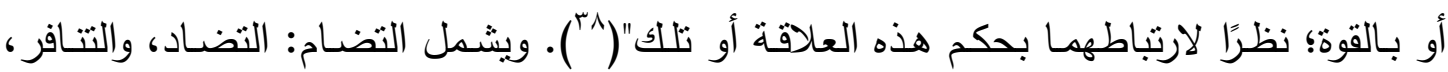

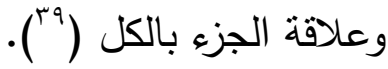

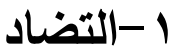

يُعد التضـاد من " الأمور الفطرية التي لا تحتاج إلى مجهود شاق؛ إذ الضد أقرب حضورًا

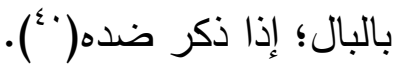

ويربط التضاد بين المفردات عن طريق الجامع العكسي، ومن أمثلة ذلك في المعلقة قوله:

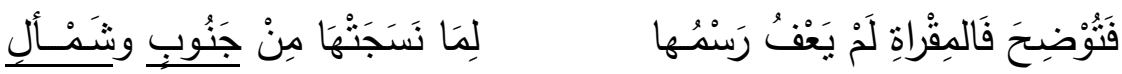

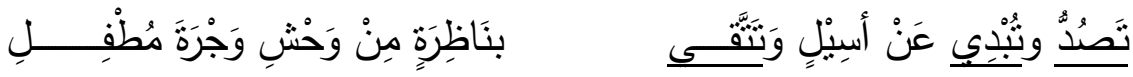

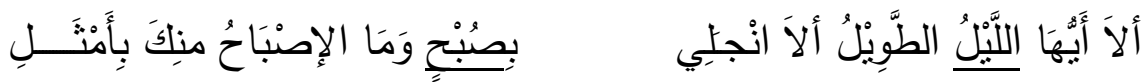

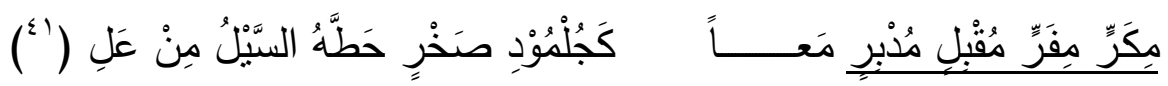
البح - محمد خطابي، لسانيات النص " مدخل إلى انسجام الخطاب"، طا، المركز الثقافي، بيروت - الدار

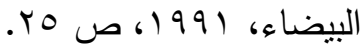

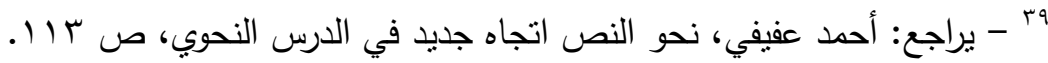
•" - أحمد إبراهيم موسى، الصبغ البديعي في اللغة العربية، دار الكاتب العربي للطباعة والنشر ، القاهرة، 
هذه الأبيات من مقاطع متفرقة في المعلقة، يؤدى الثقابل دوره الفني في ربط أجزاء البيت

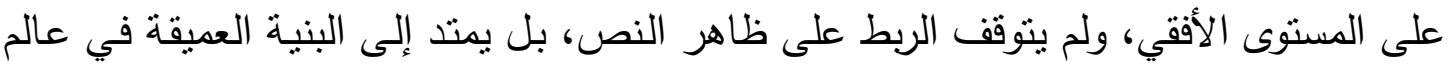

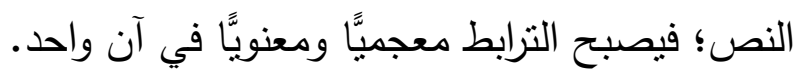

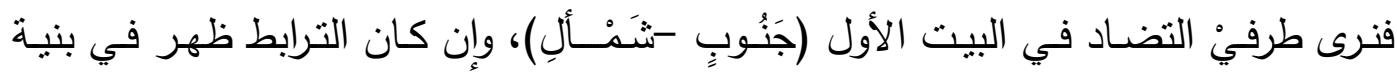

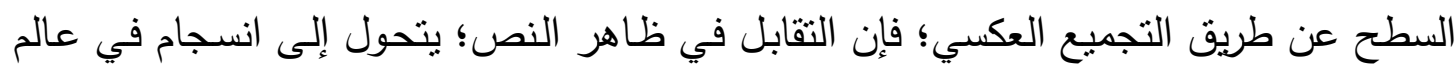
النص؛ فريح الجنوب والثمال؛ فعلا فعلهما في الطلل.

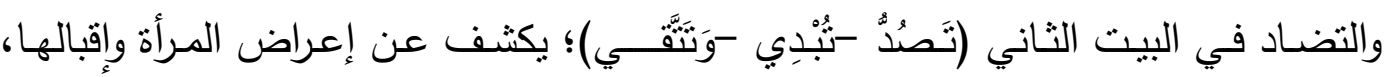

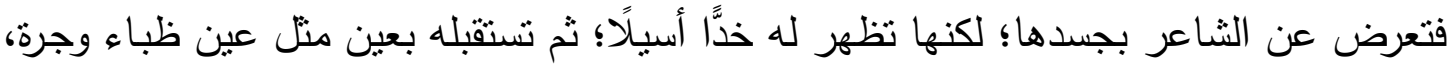

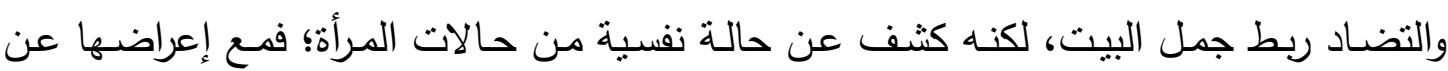
الثناعر ؛ لم تسنطع إخفاء جمالها.

الثقابل بين (اللَّنّل - صُنْحِ) في البيت الثالث؛ ترابط لفظي؛ وترابط زمني، والتزابط عن طريق الجامع العكسي في بنية السطح؛ يقابله نتظٍٍ، وتمزق نفسي في بنية العمق، وفقًا للحالة النفسية التي يعانيها الثاعر ؛ فلا الصبح بأفضل من الليل.

وتتسع مساحة التضاد في البيت الأخير ؛ليتجاوز المفردة إلى المفردتين، ويتحول الطباق إلى الئ

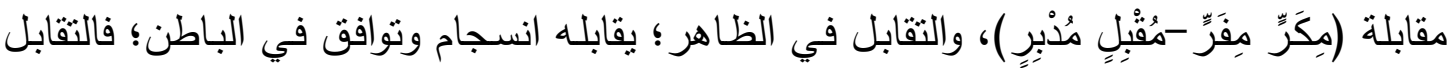
حوَّل الفرس في قوته ونشاطه إلى فرس أسطوري، يقبل ويدبر ويكر ويفر في في لهح البصر ؛ تولَّى الدال(معًا) المصاحب للتضاد مهمة الجمع بين المتناقضات.

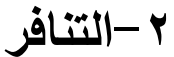

يرتبط التتافر - مثل التضـاد-بالنفي (خروف-فرس)، ويرتبط أيضًا بفكرة الرتبة (ملازمرائد)، ويرتبط كذلك بالزمن (شهور - فصول-أعوام) ... إلخ (r)؛ ومن أمثلة التنافر عن طريق النفي قوله:

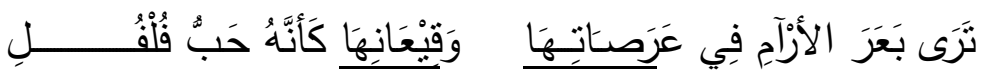

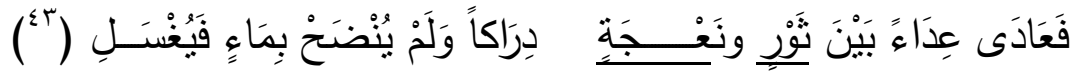
rك - يراجع: أحمد مختار عمر، علم الدلالة، طه، عالم الكتب، القاهرة، 919 (، ص 0. 1. 


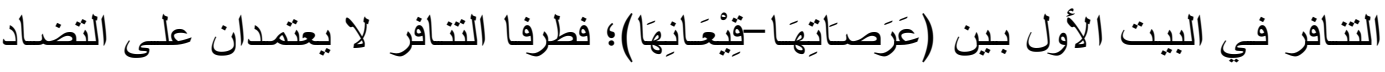

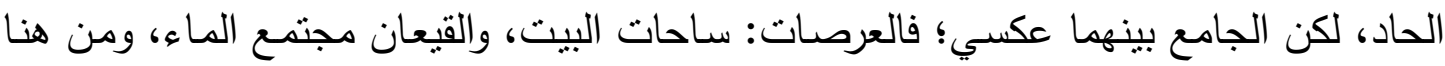

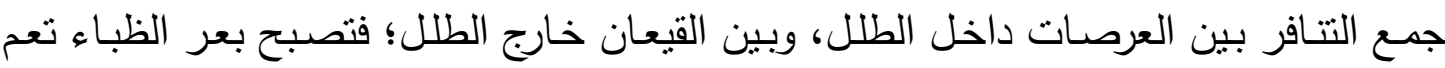
الطلل، وما حوله، وهذا تعميق لدلالة الخواء، وخلو الدكان من الأهل والأحبة.

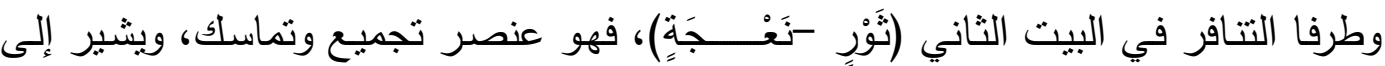

قوة الفرس ونشاطه؛ فيدرك الثور والنعجة في سرعة، دون جهد، أو عناء، فلا عرقَ، ولا كلال. والتتافر المرنبط بفكرة الرنبة في مقل قوله :

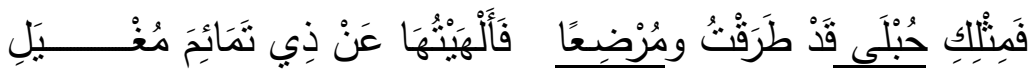

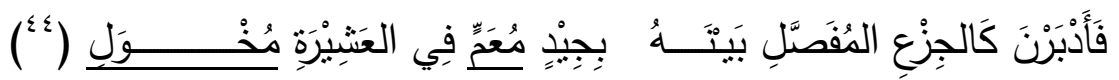

حيث جمع التتافر في البيت الأول بين (حُبْلَى-مرْْضِح)؛ فالحبلى تختلف عن المرضع في ظاهر النص؛ إن كان التتافر بين المختلفين في الظاهر؛ فإن المستوى الدلالي يجعلهما في حال تماه؛

حيث يجمع بينهما تعلقهما بالثاعر - وهما أقل اشتهاء للرجال - ليثبت الثاعر لنفسه الرجولة والفحولة، وجمع كذللك بين (مُعِّم - مُخْوَلِ)؛ عن طريق تتافر الرتبة، فالعم يختلف عن الخال من الناحية اللفظية، بينما من الناحية الدلالية؛ فقد شبه الثناعر سرب البقر الوحشي بالعقد في عنق

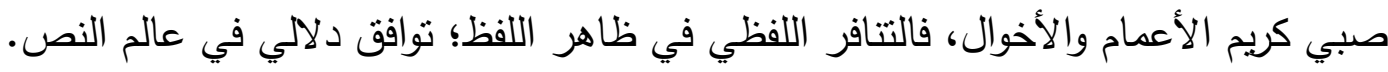
ويتجلى التنافر الزمني في قوله:

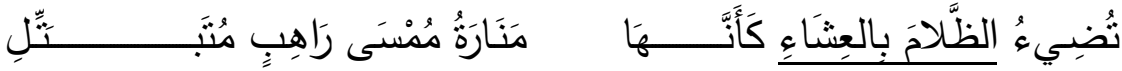

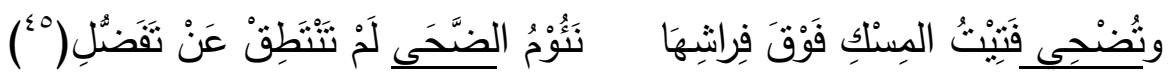

التتافر الزمني في هذين البيتين تمتد مساحة التماسك من خلاله؛ ليربط بيتين؛ حيث تم

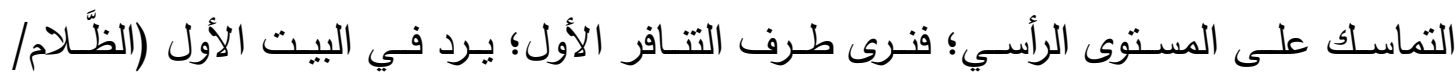

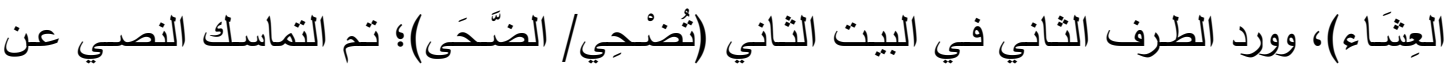

$$
\begin{aligned}
& \text { צ' - امرؤ القيس، ديوانه، ص 9، بr } \\
& \text { ؛؛ - السابق، ص ז Iا، זr. }
\end{aligned}
$$

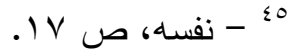




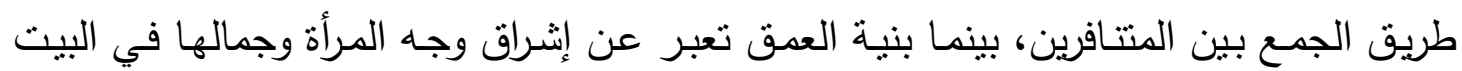
الأول، وتتثير الدلالة في البيت الثاني إلى رفاهية هذه المرأة؛ فهي مخدومة، ولانئ تقوم على خدمة نفسها؛ فلا تتافر في بنية العقى.

\section{r-علاقة الجزء بالكل}

هي علاقة تلازم بين الثيء وجزئه؛ مثل علاقة اليد بالجسم، وعلاقة العجلة بالسيارة (") . والأمثلة في هذا الصدد كثيرة؛ فمن نماذجه في المعلقة:

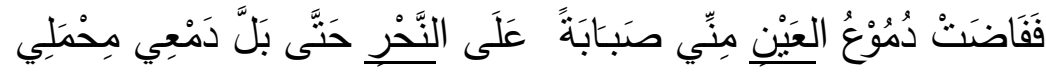

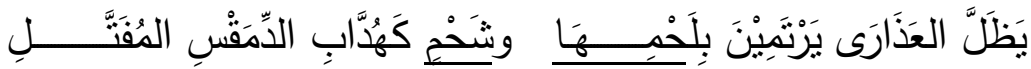

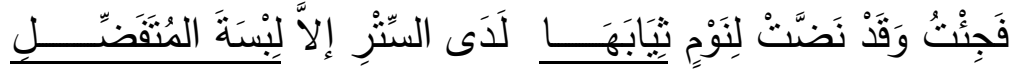

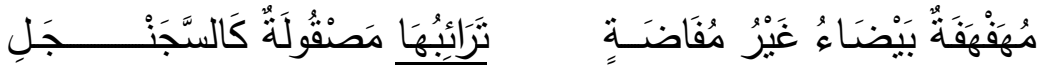

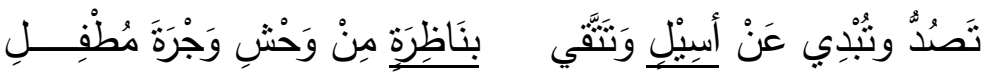

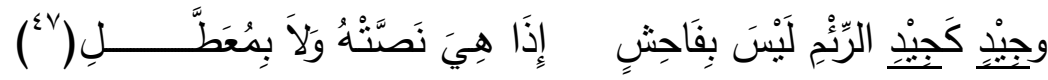

$$
\text { ونتبين علاقة الجزء بالكل على النحو الآتي: }
$$

$$
\begin{aligned}
& \text { جسد الثاعر : العين - النحر. } \\
& \text { الناقة : اللحم- الثحم. } \\
& \text { المرأة: ثياب- لبسة المتقضل. } \\
& \text { المرأة: } \\
& \text { المرأة: أسيل- ناظرة. }
\end{aligned}
$$

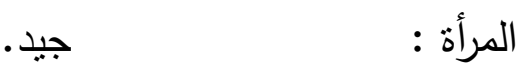

$$
\text { ฯ^ }
$$




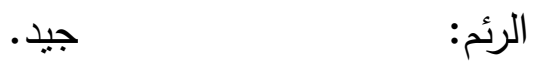

من الملاحظ أن العلاقات في هذه النماذج تقوم على علاقة الجسد بأحد أجزائه، والعلاقة

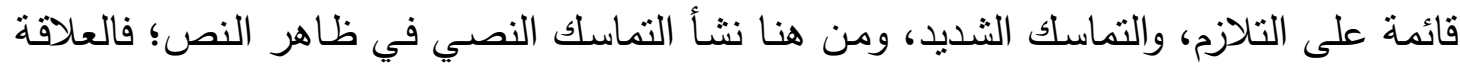

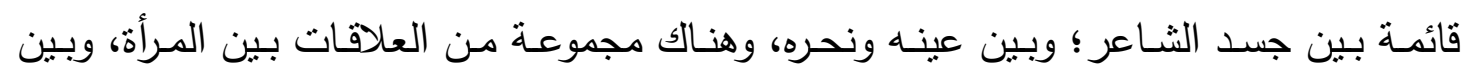

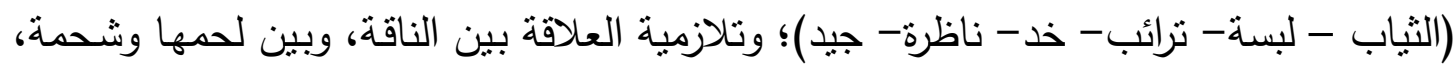

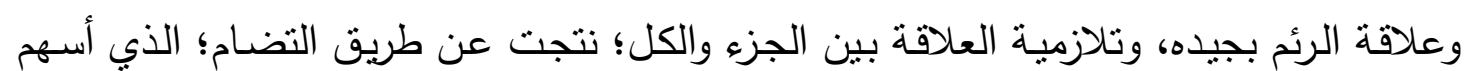
إسهامًا فعالًا في تماسك النص على ونى المستويين اللفظي والدالآلي.

\section{r- ب التعريف والتنكير}

التعريف والتتكير وسيلتان تعمـلان في ظـاهر النص أصـالة، وتعمـلان في عالمـه بالتبعية؛ فيمكن " شرح التعريف بأنه العناصر الداخلة في عالم النص؛ إذ تكون وظيفة كل منها لا تحتمل الجدل في سياق الموقف، ومعنى أن تحدد الوضع باسم علم مثنلً، أو بصفة هي معرفة؛ أنك أنك

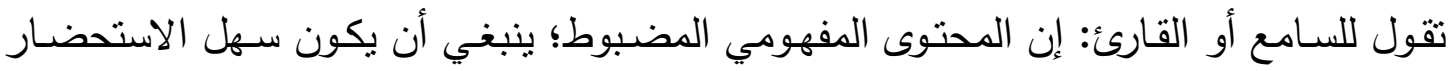
على أساس المساحات المعلومية المنشطة بالفعل.

أما عناصر النكرات؛ فتتطلب من ناحية ثانبة تتشيطًا لمساحات معلومية أخرى؛ إن علامات

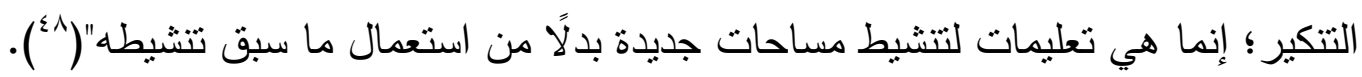
ومسن هنا؛ تكون أداة التعريف تشبير إلى مـا يسهى بالمعلومـات السـابقة؛ بينمـا تؤدي أداة

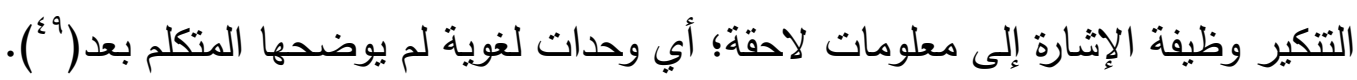
ونختار مثالًا واحد لكلا النوعين؛ فمثال التعريف مطلع المعلقة:

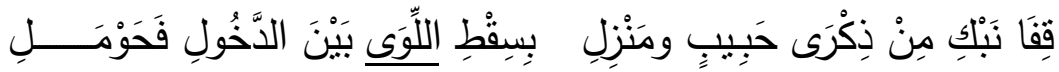

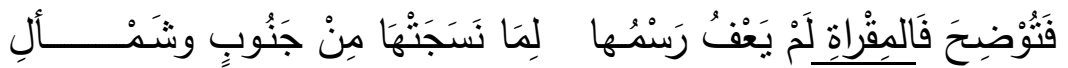

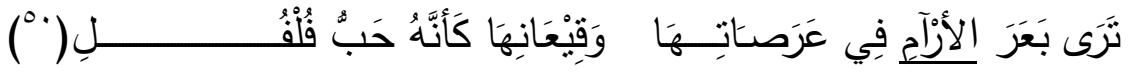

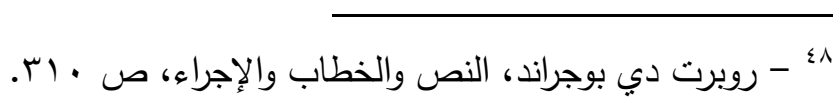

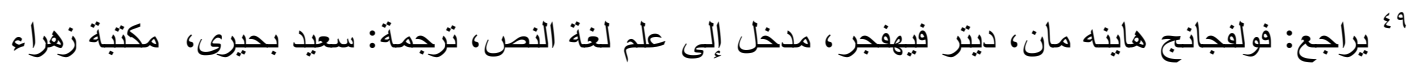

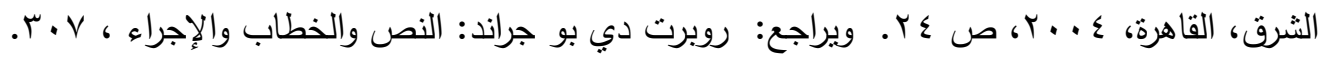

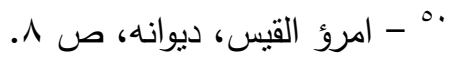


نلحظ أن هناك علاقة وثيقة بين مركز الضبط ( حبيب ومنزل)، وبين المعرف بـ (ال) في

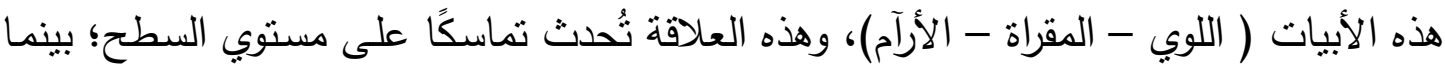
التعريف ينشط مساحة من المعلومات بين التعريف، وبين منزل الحبيبة، وكذلك التعريف؛ ينشط التطائ

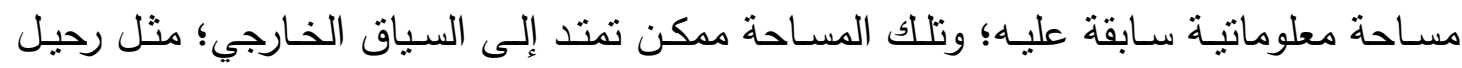

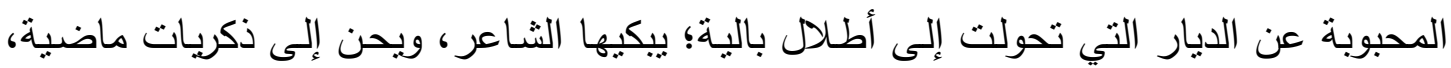
وتنوق نفسه إلى عودة الحبيية الراحلة.

والدور نفسه في سبك النص؛ يمتد إلى التتكير ، ونماذجه في المعلقة كثيرة جدًا، ونكتفي بمثال واحد حتى لا يضيق بنا المجال:

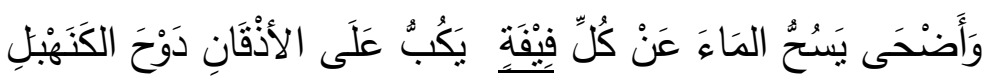

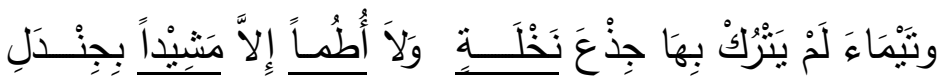

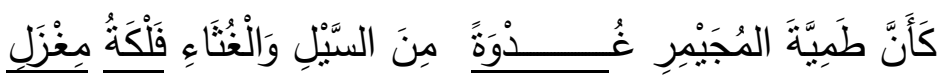

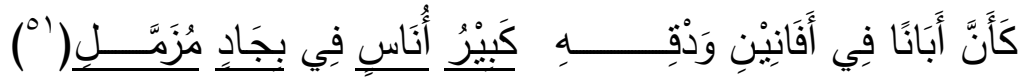

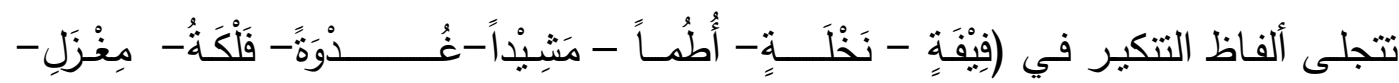

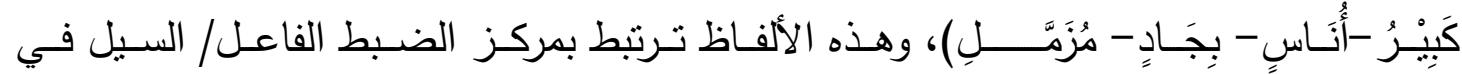

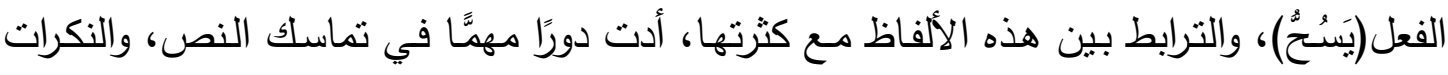
نشطت مساحات معلوماتية سوف تأتي؛ بدأت من مركز الضبط / السيل، وتأثنيره على الكون والأثشياء من بداية المقطع حتى نهاية القصيدة.

\section{ع - - الحذف}

الـذف نـوع مـن الإيجـاز ؛ حيـث قسـم البلاغيـون الإيجـاز إلـى إيجـاز القصـر وإيجـاز

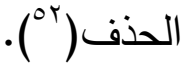
ويُعرَّف الحذف بأنه " هو حذف ما يكون بحذف كلمة، أو جملة، أو أكثر مـع قرينـة تُعيّن

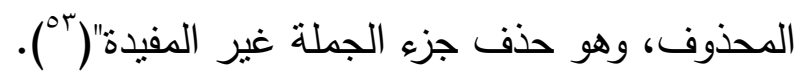
| 1

ror - يراجع: الخطيب القزويني، التلخيص في علوم البلاغة، ضبط وشرح: عبد الرحمن البرقوقي، طب، الككتبة

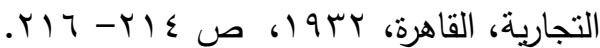


والحذف الذي تردّّد في المعلقة؛ حذف الكلمة، وحذف الكلمـة عند البلاغيين؛ هو حذف المضاف وحذف الصفة، وحذف الموصوف، وحذف فعل الثرط، وحذف جواب الثرط(

ويُحذف الفعل، ويحذف الفاعل والمفعول؛ لضرورة فنية، وقد نبَّه النصيون على أهمية الحذف في سبك النص؛ لأن " البنيات السطحية في النصوص غير مكتملة - غالبًا - بعكس ما قد يبدو

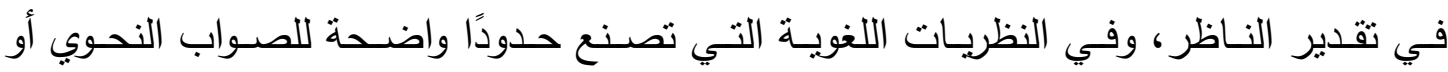

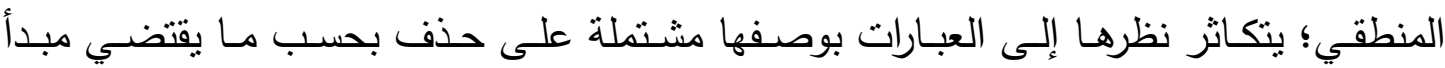

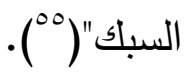

والحذف مثال آخر للتتاوب بين الإيجاز وسرعة الإتاحة، وينطلب الحذف جهدًا أكبر لربط نموذج العالم التقديري للنص بعضه ببعض في الوقت الذي يقتطع من البنية السطحية بشدة،

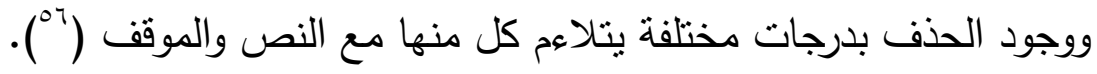
ويمكن اختيار نموذج واحد فقط لكل نوع من أنواع الحذف الذي ورد في المعلقة:

\section{- حذف المضاف والموصوف}

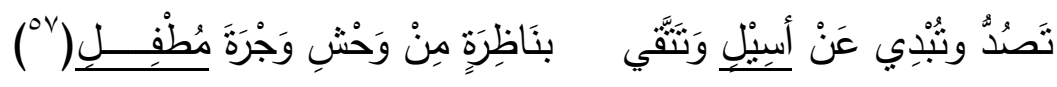

حذف الموصوف في الثطر الأول في ( أسيل) أي " مـن خد أسيل؛ فحذف الموصـوف

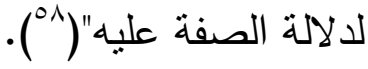
أما حذف المضاف في الثطر الثاني؛ ففي (مطفل)، والثقدير " بناظرة من وحش وجرة ناظرة

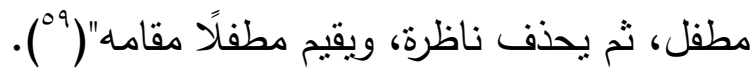

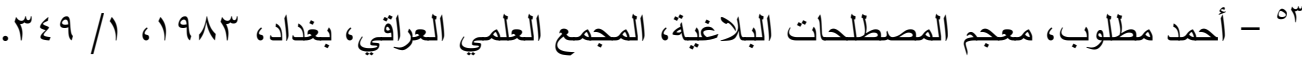

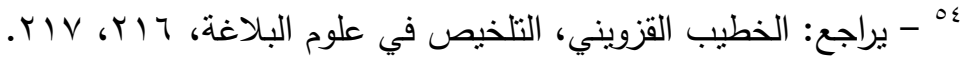

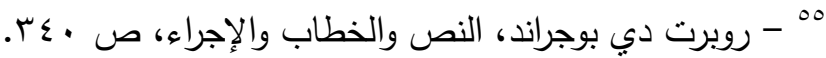

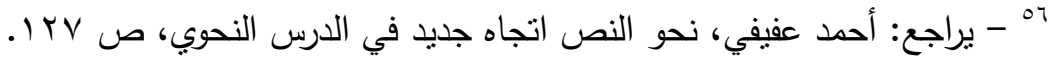
الم ^^ - - الحسين بن أحمد بن الحسين الزوزني، شرح المعلقات السبع، تحقيق: محمد عبد القادر أحمد، طا، مكتبة

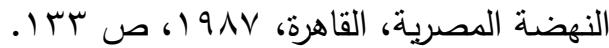
9ه - إسماعيل بن يونس النحاس، شرح القصائد التسع المشهورات، تحقيق: أحمد خطاب، دار الحرية للطباعة،

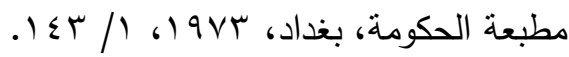




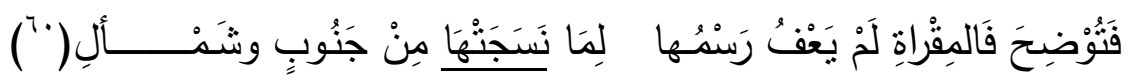
حُذف الفاعل في ( نسجتها)؛ حيث إن " في نسجت ذكر الريح؛ لأنها لما ذكرت المواضع

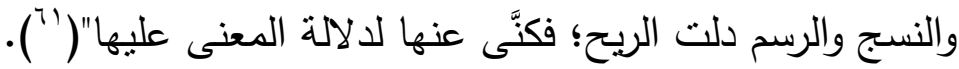

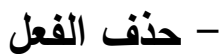

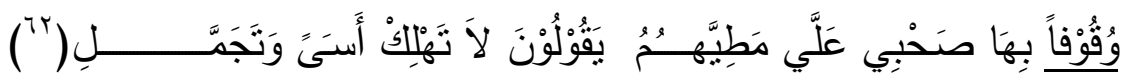
يكمن الحذف في المصدر وقوفًا، أو المفعول المطلق، فقد حذف الثـاعر فعل الأمر (قف)، ودل المفعول المطلق على الفعل المحذوف.

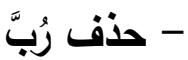
تكثر نماذجه بصورة لافتة في المعلقة؛ يقول الثاعر:

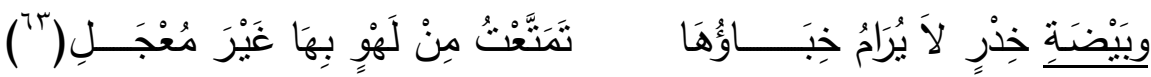

الحذف في بداية البيت في (وبيضة)؛ حيث حذف الثناعر حرف الجر (رب)، ودلت واو

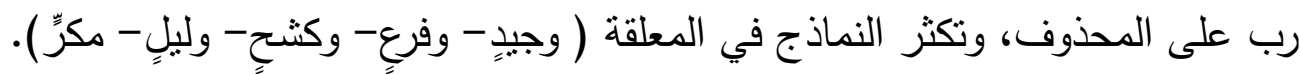
الإيجاز الكامن في الحذف، يُعد عنصرًا مهمًّا في سبك النص؛ فالحذف لا يطرد عنصرًا بأكمله؛ بل هو اقتصاد في ذكر الملفوظ بكل عناصره( والحذف مرتبط عادة بالنص لا الجملة، وفي الغالب يكون واقعًا بين جملتين؛ حيث نجد في الجملة الثانيـة فراغًا بنيويًًا، يبحث المخاطَب عنه معتددًا على مـا ورد في الجملة الأولهى، أو

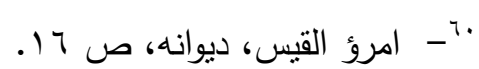
" - أبو بكر محمد بن القاسم الأنباري، شرح القصائد السبع الطوال، تحقيق: عبد السلام هارون، طء، دار

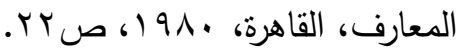

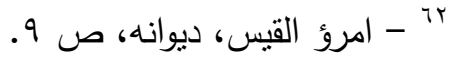

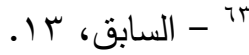

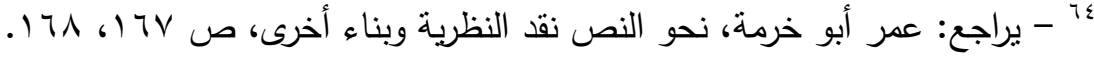


النص السابق، ومن هنا تصنع المحذوفات تماسكًا بين أجزاء النص؛ حيث يُعد الحذف علاقة

إن الاقتصاد في المحذوفات؛ بصنع تماسكًا في ظاهر النص، بينما تردد ذهن المتلقي بين

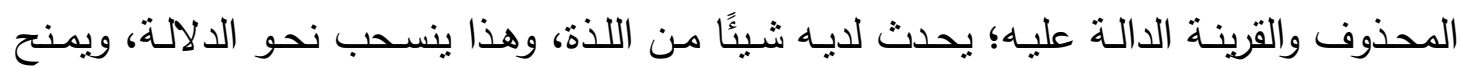
النص تماسكًا دلاليًا؛ بجانب التماسك الرصفي في ظاهر النص. لنص.

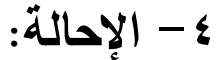

تعمل الإحالة على تماسك النص؛ حيث تربط أجزاء النص المتقاربة والمتباعدة؛ فتقوم " شبكة

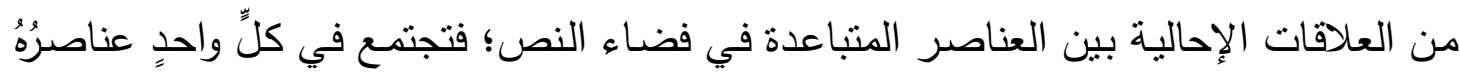
متتاغمة، وهذا مدخل الاقتصاد في نظام المعوضات في اللغة؛ إذ تختصر هذه الوحدات الإحالية

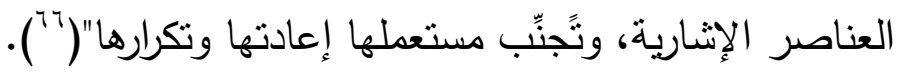

وتؤدي الإحالة دورًا مهمًّا في تكوين النص، والنصية، وسبك النص، وحبكه( لآ)، ومن هنا

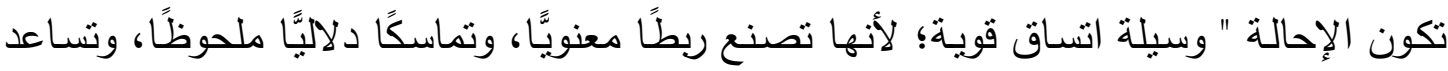

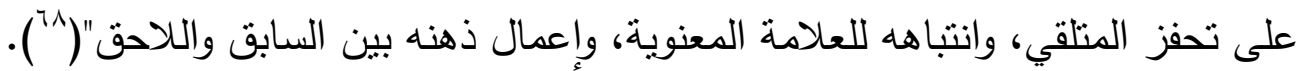
وتتقسم الإحالة إلى: إحالة مقامية، وإحالة نصية، والمقامية تحيل إلى خارج النص، والنصية

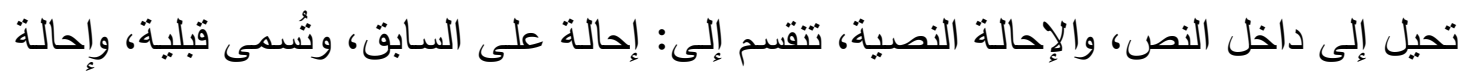
على اللاحق، وتُشمى بعدية. وتتفرع وسـائل الإحالـة إلىى: أسماء الإثـارة والموصـولة، والضمائر، وأدوات المقارنـة مثل:

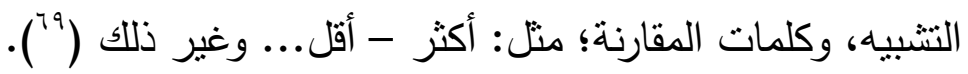

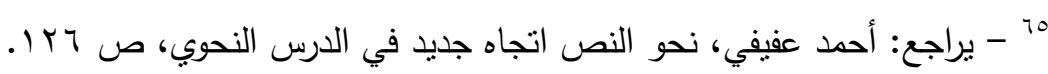

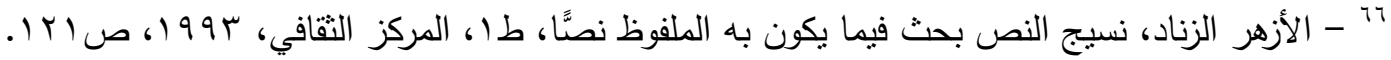

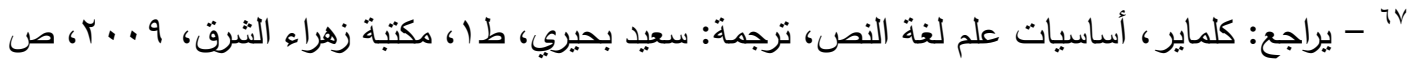

1^" - أحمد عفيفي، الإحالة في نحو النص دراسة في الدلالة والوظيفة، ضمن كتاب مؤتمر كلية دار العلوم

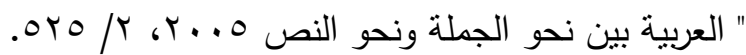

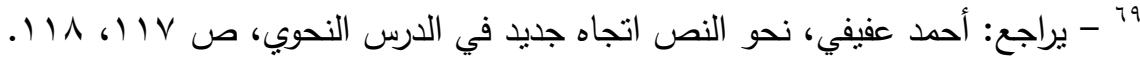


اختقت من المعلقة أسماء الإشارة، والأسماء الموصولة، وكثرت الإحالة بالضمائر ، والمقارنة،

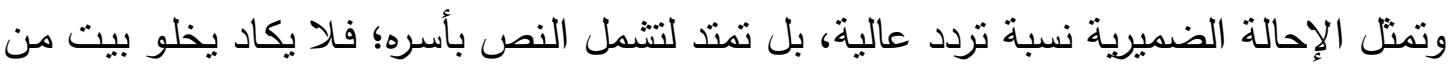

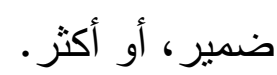

وهذا النوع من الإحالة ذات المدى البعيد؛ فالثناعر هو الثخصية الرئيسية في المعلقة،

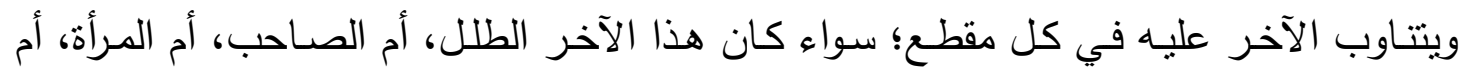

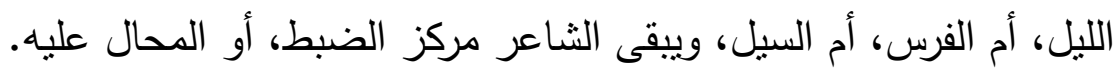

ونقف على نموذج واحد فقط، ومـا ينطبق عليها ينطبق على كل مقاطع المعلقة، يقول الثاعر:

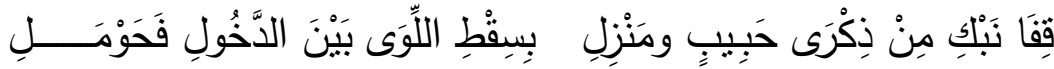

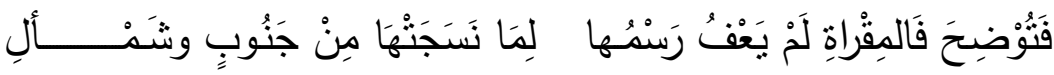

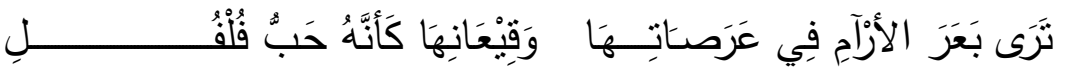

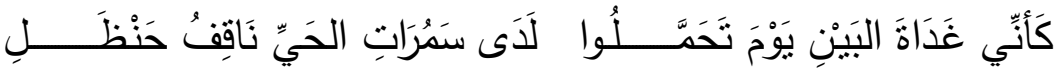

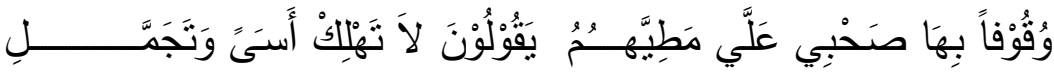

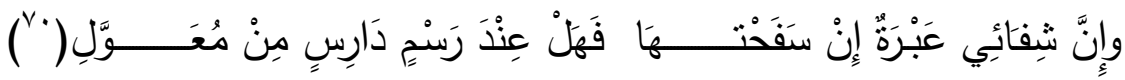
إن الضمائر التي تحيل على الثناعر في المعلقة بأسرها؛ تكفي لتماسك النص سبكًا وحبكًا، بينما هناك إحالات أخرى تعضد من ترابط النص، وتماسكه، وفي هذا المثال نرى الضمائر؛ تحيل على الثاعر، والصحب، والحبيبة، والمنزل، ويمكن تنينها على النحو الآتي:

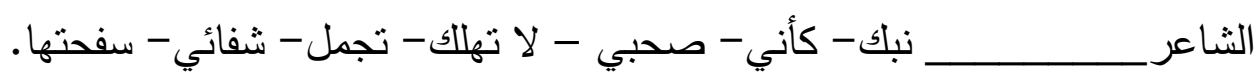

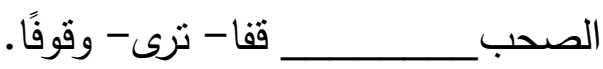

$$
\begin{aligned}
& \text { تحملوا - مطيهم. } \\
& \text { رسمها - عرصاتها - قيعانها. }
\end{aligned}
$$


الإحالة هنا مداها بعيد؛ فوصلت الجمل المتباعدة على مستوى الفقرة، وعند البحث عن

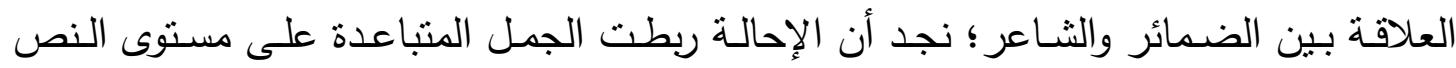
بأسره. وهذه الفقرة تسير في شكل تسلسل ضميري؛ يحافظ على اتسـاق النص، فالنص " تتابع

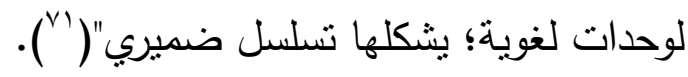
والإحالة تسهم في سبك النص، وتمتد إلى منطقة الدلالة بالرجوع إلى المعنى في النص، والضمائر في الدقطع السابق مرتبطة بالفعل، والاسم، وتتتوع بين ضمير التكلم، وبين ضمير الغياب، وهذا التتوع في بنية السطح؛ يتبعه تتوع دلالي في البنية العميقة. وتكثر الإحالة عن طريق المقارنة في المعلقة، ولم ترد كلمات المقارنة إلا مرة واحدة (وَمَا

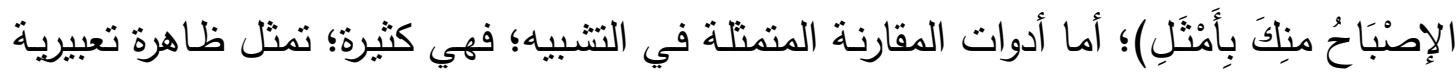

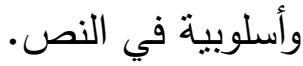

تكررت ( كأن) سا امرة، وتكرر حرف التشبيه ( الكاف) § ا مرة، ووردت (مثل) مرة واحدة،

وورد التشبيه عن طريق المفعول المطلق مرتين واحدة، وورد التتبيه الضمني مرة واحدة. ونختار مثالًا واحدًا، نرى فيه نوالى النتبيهات، والمراوحة بين حرف التشبيه ( كأن - الكاف)؛ :

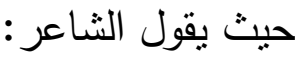

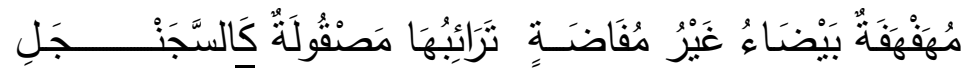

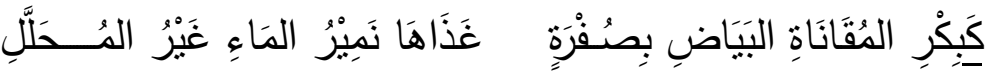

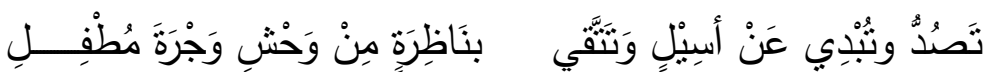

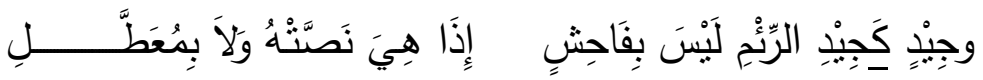

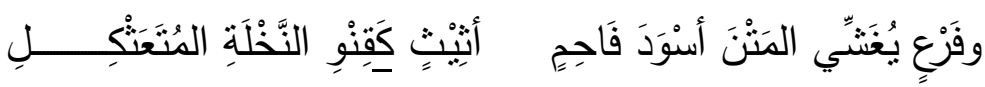

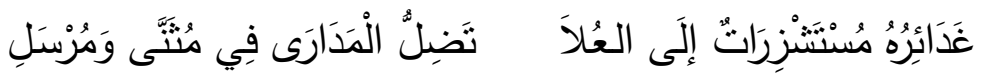

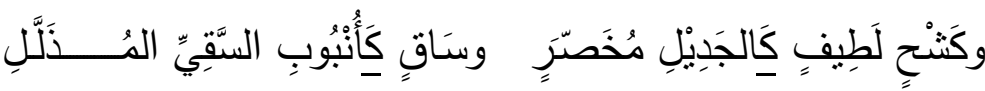

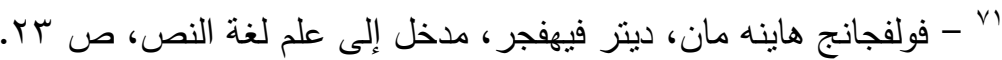




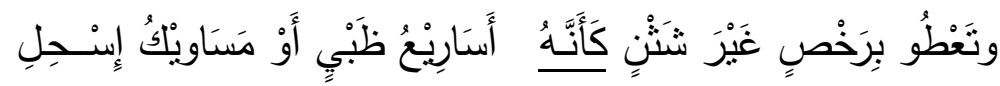

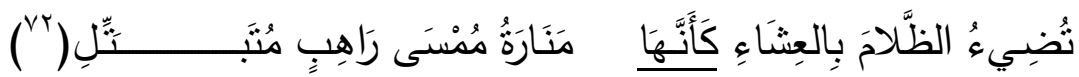

ترددت ( الكاف) في الأبيات ثماني مرات؛ بينما ترددت (كأن) مرثين، ويمكن النظر إلى في

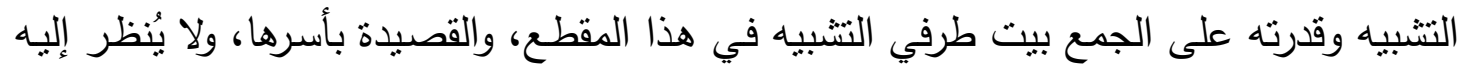
على مستوى البيت المفرد، ولا ننزعه من نصده، بل ننظر إليه على حسب سياقه، ولم تتوقف

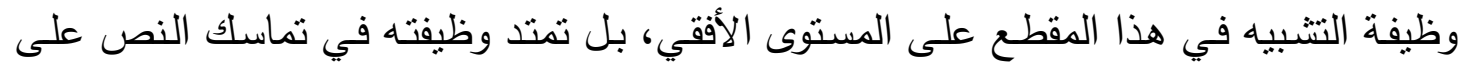

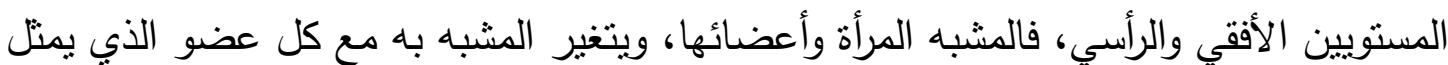

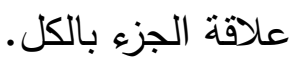

ومهمـا يكن من شـأن؛ فإن التتبيه؛ أسهم في سبك النص عن طريق أداة التشبيه لإقامة تتشابك بين ما قبلها وما بعدها؛ لكن القدرة الحقيقية للصورة التتبيهية؛ هي تطعيم الصورة؛ بما

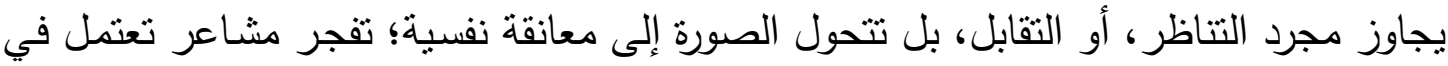

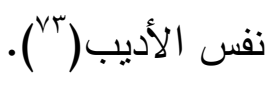

إذًا تغلُّغل التتبيه في المعلقة بهذه الصورة اللافتة للنظر ؛ يجعل له القدرة على تماسك النص

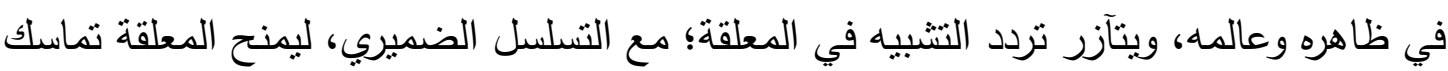
البناء على المستوى اللفظي، والتزابط الداخلي على المستوى المعنوي.

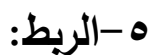

إن وسائل الربط تكفل للنص سلامة الاتصال بين أجزائه، وأمن اللبس في فهم المقصود من

هذه الأجزاء، وعدم الخلط بينها (ع (vل).

وقد اتضح مما سبق أن التكرار ، والإحالة، والحذف؛ بحافظ على بقاء مساحات المعلومات؛

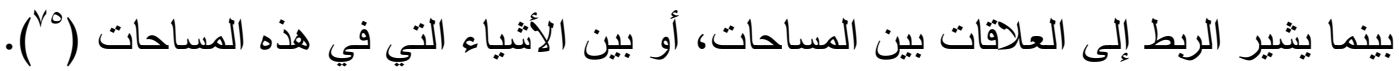

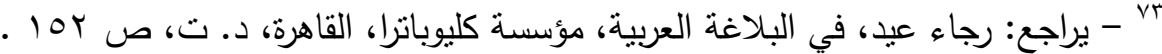

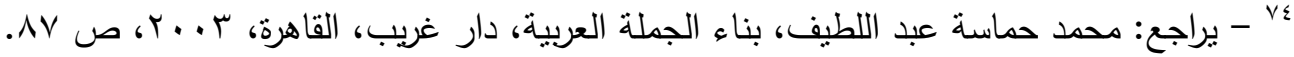

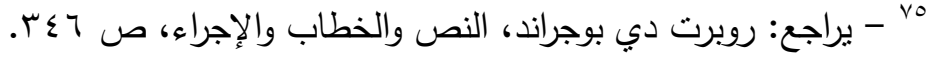




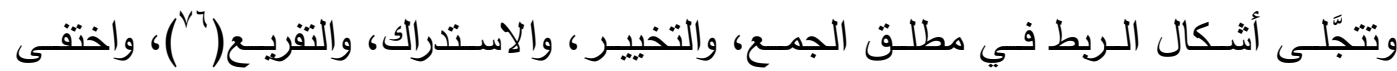
الاستنراك، وقلت نماذج التخيير، ويتم مطلق الجمع عن طريق الواو، ويرتبط التفريع في كثير

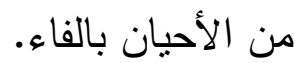

والربط بالواو ، والفاء تكثر نماذجه بصورة لافتة، فقد تكررت الواو 0 مرة؛ بينما ترددت الفاء

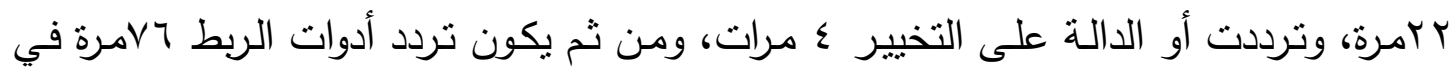
المعلقة، وهي نسبة مرتفعة؛ تتساند مع ما سبق من وسائل السبك في تماسك النص. ونختار مثالًا واحدًا يجمع بين الربط بالواو والفاء، وأو؛ يقول الثاعر :

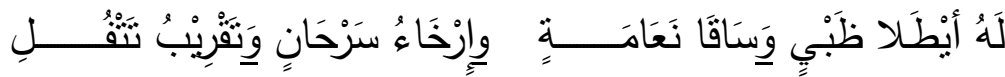

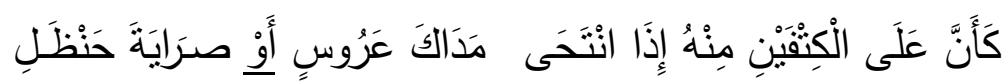

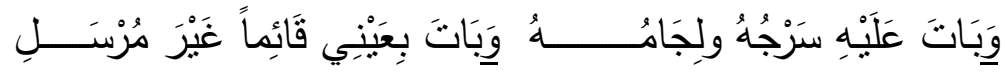

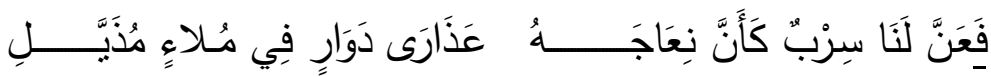

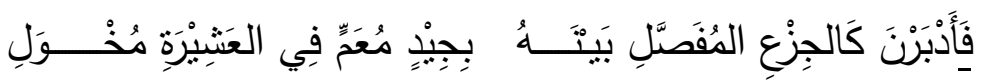

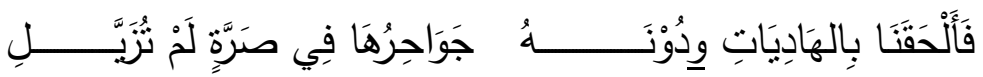

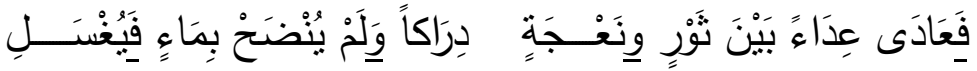

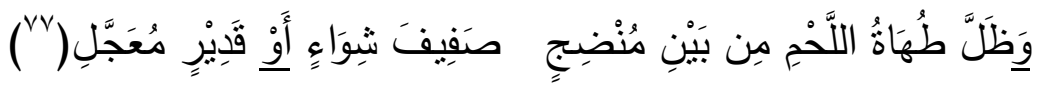

تكررت ( الواو) 9 مرات في هذا المقطع، وتكررت (الفاء) ه مرات، وترددت (أو) مرتين،

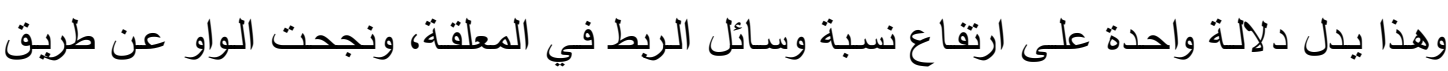

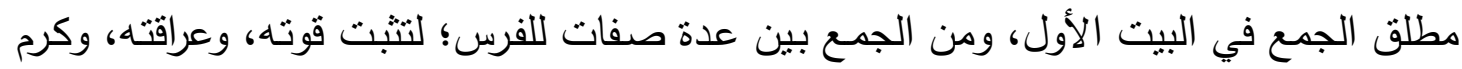

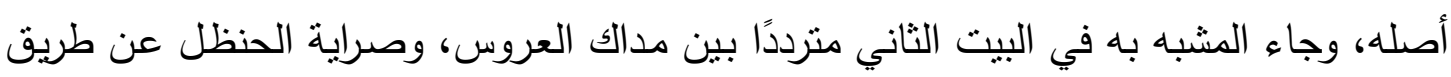

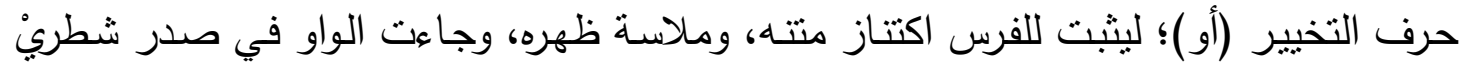

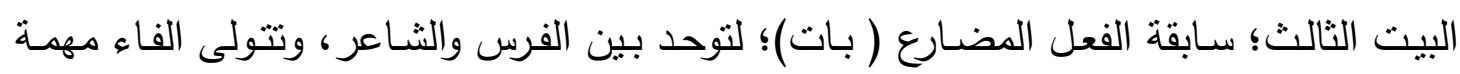

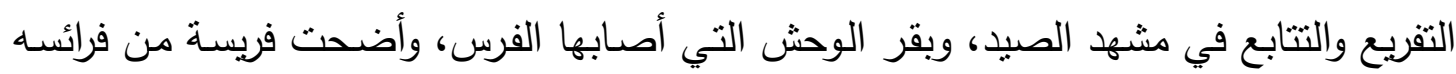

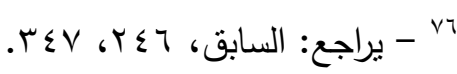

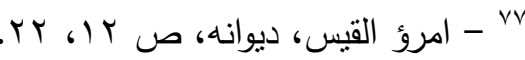




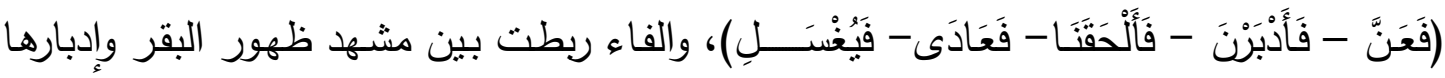
في حركة من التتابع والسرعة؛ لنتير إلى ذعر البقر من الفرس، وتتولى ( الفاء)، مهمة ربط وليط

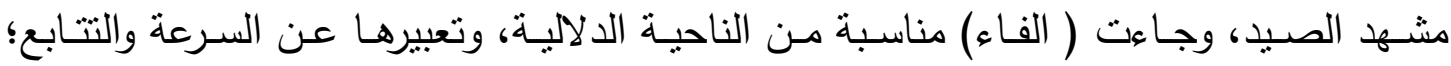
وتتساوق مع قوة الفرس، ونشاطه، ومهارته؛ فلا ينرك فرصة لهروب البقر .

وتساوقت الواو مع الفاء في مهمة تماسك النص على مستوى الظاهر ، والباطن؛ فجمعت

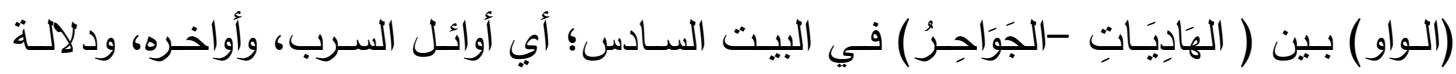

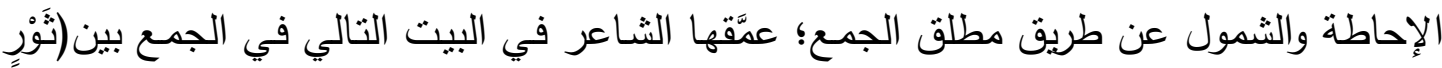

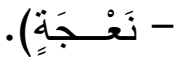

وينهي الثـاعر المقطع؛ بالنتيجة والهدف من الصيد في البيت الأخير ؛يتحول الصبد إلى

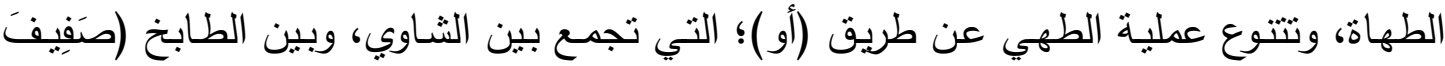

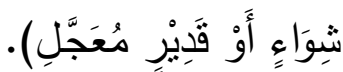

ومهما يكن من شن؛ فإن كانت المحتويات صادقة في مطلق الجمع؛ فإن عنصر الصدق، لا

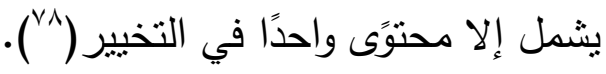

والربط عن طريق الواو ، والوفاء؛ لا يوقف عند بنية السطح؛ بل يربط مساحات واسعة من

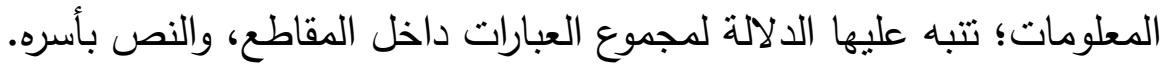

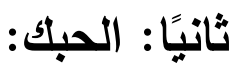

يُطلق على الحبك الترابط الدفهومي؛ فهو مختلف عن السبك، أو الترابط الرصفي؛ فمعيار السبك يختص بالاستمرارية المتحققة في ظاهر النص؛ بينما يختص الحبك بالاستمرارية الدلالية

ومن هنـا يكون الحبك اتسـاق دلالي، و" البحث عن الانسجام النصي؛ يحيلنا إلى رصد

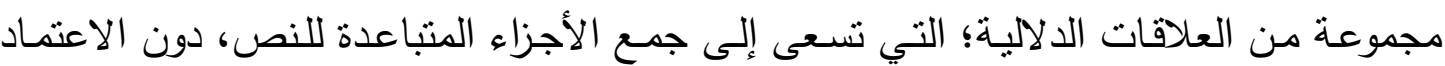

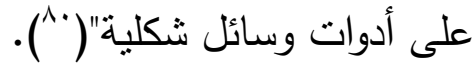

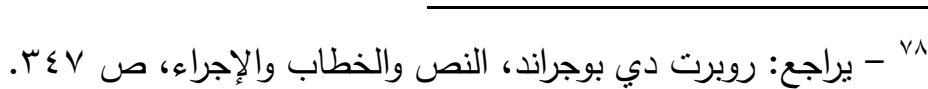

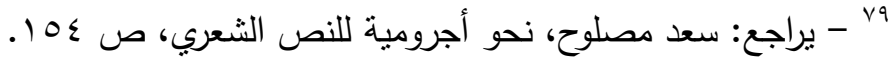

•^ - ليندة قياس، لسانيات النص النظرية والنطبيق مقامات الهمذاني نموذجًا، طا، مكتبة الآداب، القاهرة، 
وقد يبدو النص في حالة من التفكك في بنية السطح؛ لكن من خلال القراءة الواعية؛ نتبين

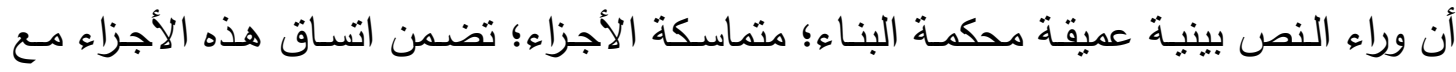

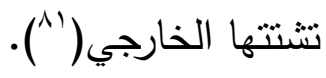
وربما ثُقدم الوحدة الدلالية على وحدة الثكل؛ فُبنظظر إلى النص على " أنه وحدة دلالية،

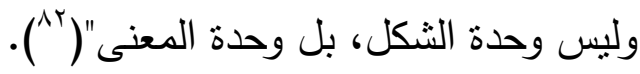

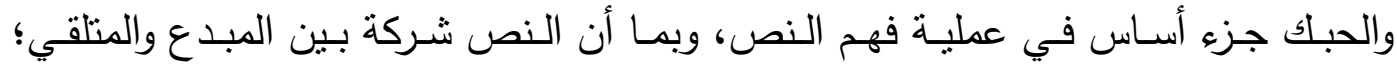

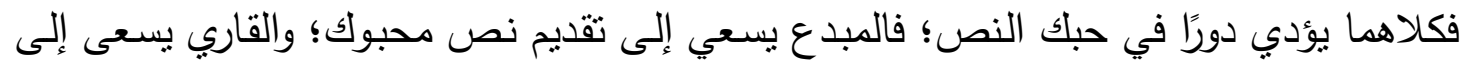

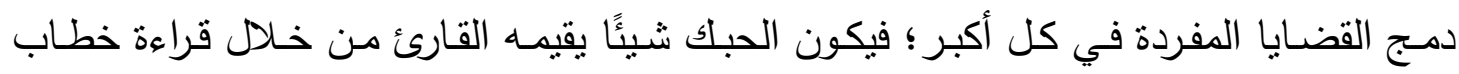
مترابط معتمدًا على قاعدة الاستتناج. وينطلق المبدع عند تثكيل نصه من توسعته بطرق مختلفة؛ اعتمادًا على المقصد والحالة،

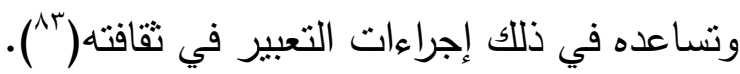

ومن ثم نبحث عن روابط دلالية في معلقة امرئ؛ وهناك مجموعة من النقاد بحثوا عن روابط

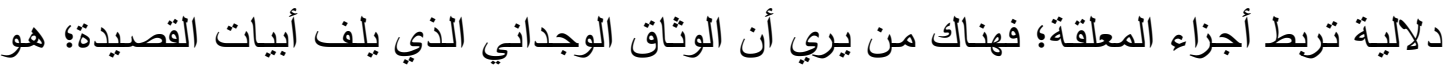

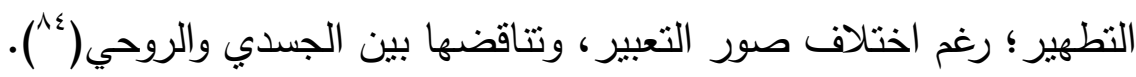
ومنهم من رأى أن فكرة الإثباع هي الرباط الدلالي في القصيدة؛ فالقصيدة جمعت لحظات

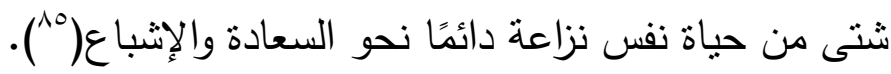
أمسا الرباط الذي يربط القصيدة؛ فهو الموت عند مصطفى ناصف؛ فالطلل يرمز لمشكلة

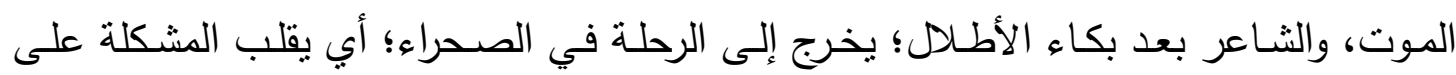

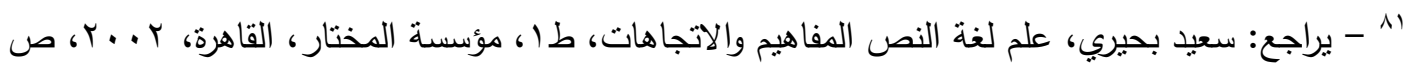

r rr .1 TN 6) TV

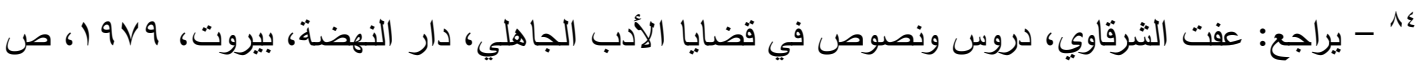
. $r \leqslant Y-r T r$

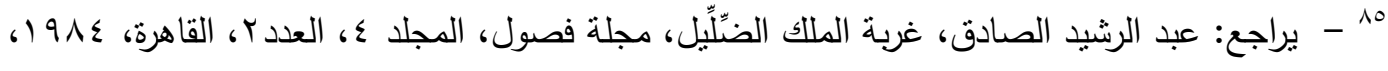


وجهها: المضي، أو الرحلة، أو الموت؛ فلا ينفصل الثعور بالموت عن وصف الناقة؛ فالفرس

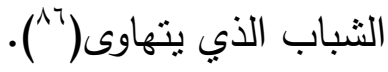

و"الوجود كالليل، وهذا الفرس هو الإنسان يسير مع الليل. حقًّا إن امرأ القيس حكى مغامراته

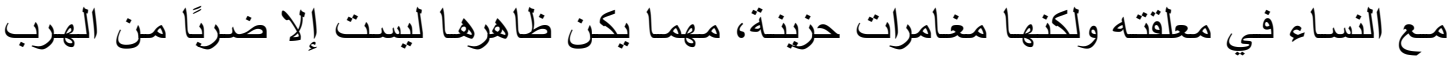
كهرب الفرس إن علينا أن نربط بين الفرس والليل، وهذه المغامرات إذ ذالك يتضح لنـا أن امرأ

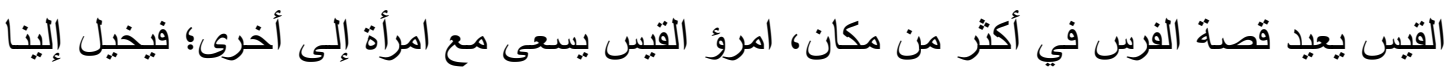

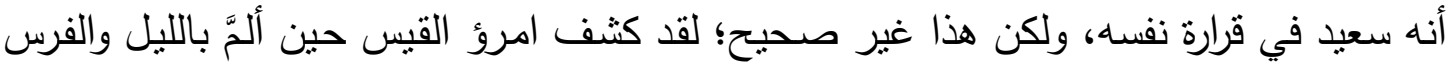
بواعث هذه الغزوات النسائية، وإنه هو الآخر خائف من الموت، وليس بين المقبل على الحياة

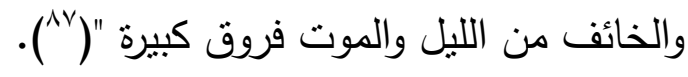

وربط مصطفي ناصف المقطع الأخير ( وصف المطر ) بالموت؛ حيث أنه يؤدي دورًا مزدوجًا في الثـعر الجـاهلي؛ فاقترن بالحياة، وكان مرادفًا لهزيــة الموت، وربط المطر بتوالي الليل

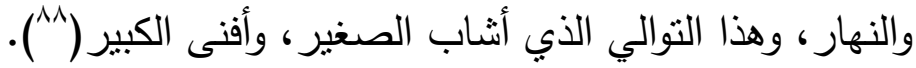

وهذه الروابط الدلالية مقبولة؛ حيث إن النص الأدبي يقبل تعدد القراءات؛ ويمكن البحث عن روابط دلالية أخرى؛ فالأنا رباط وثيق في المعلقة؛ فأنا الثاعر حاضرة في وصف الطلل؛ لكنها لإبها

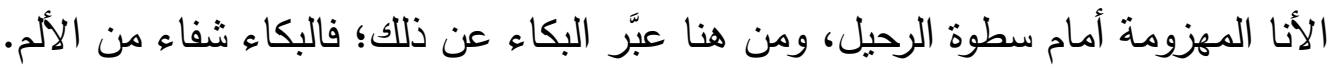
وانتقل الثـاعر بعد ذلك إلى مغامراته النسائية، وتبدو الأنـا الثـاعرة؛ في حالة من النشوة والسعادة؛ لكن الأمـر غير ذللك؛ فـلا تختلف الذات في هذا الدقطع عن المقطع السـابق؛

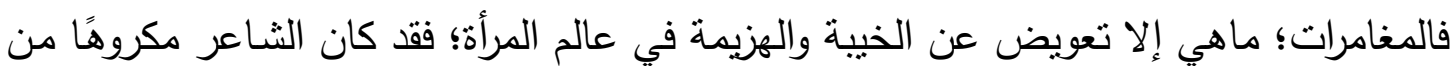
النساء، ومن هنا ذكر تعلُّق الحبلى والمرضع به، وهما أقل الشتهاءً للرجال.

وكان الثناعر يعاني من مشكلة؛ أدت إلى نفور النساء منه، ولعل رواية إحدى زوجاته، تؤكد

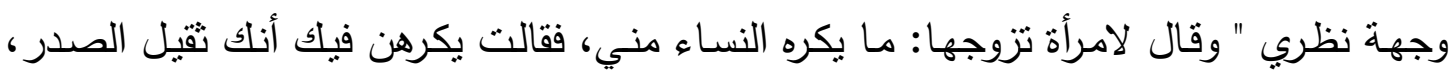
وخفيف العجز، سريع الإراقة، بطيء الإفاقة، وسأل أخرى عن مثل ذللك فقالت: يكرهن منك أنكا

צ^ - يراجع: مصطفى ناصف، دارسة الأدب العربي، الدار القومية للطباعة والنشر ، القاهرة، د.ت، ص سبr. tOY ror |^ 
إذا عرقت فحت بريح كلب؛ فقال أنتِ صدقتتي إن أهلي أرضعوني لبن كلب، ولم تصبر عليه

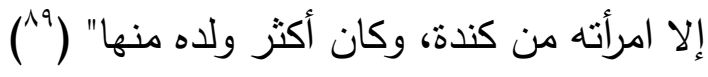

الرواية الثانية غير منطقية؛ فلبن الحيوان؛ لا يغير من عرق الإنسان، وتلك الراوية أعجبت

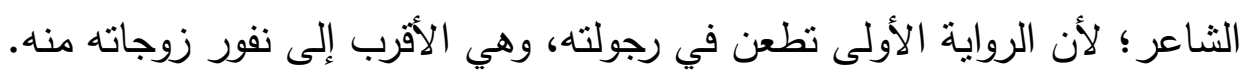

وتبدو الذات منسحقة في عالم الواقع، أو الحياة الاجتماعية؛ فيأتي مقطع وصف الليل؛ معبرًا

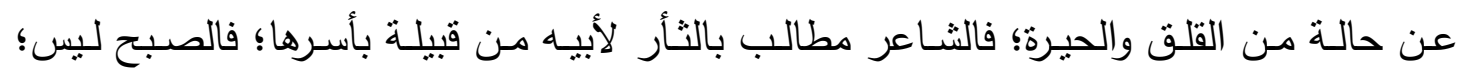
بأفضل من الليل؛ فالصباح مواجهة المصنير.

ومن ثم أنبع وصف الليل بوصف الفرس؛ الذي تحول إلى فرس أسطوري؛ والفرس معادل

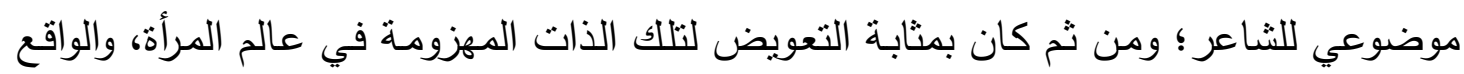
الاجنماعي.

ولم تلبث هذه الأنا إلا أن تعود إلى خيبتها وانكسارها في المقطع الأخير ( وصف المطر)؛

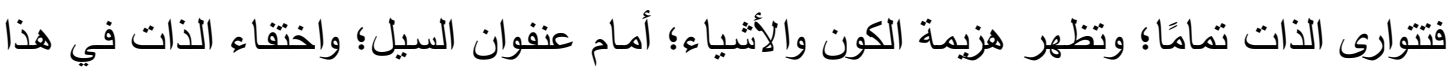
المقطع؛ ما هو إلا هزيمة الثاعر ؛ فقد خرج إلى القبائل يطلب منهم المعونة على بنى بني أسد؛ يثأر لأبيه؛ فلم يجد معينًا؛ فذهب إلى قيصر ؛ يطلب منه المعونة، وكانت هذه السفرة سبيًا في هلاكه. ومهمـا يكن مـن أمر ؛ فإن التطهير، أو الإثباع، أو مشكلة الهوت، أو الأنا كلها روابط

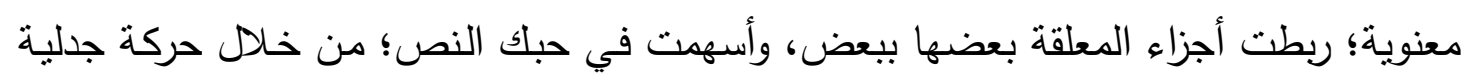

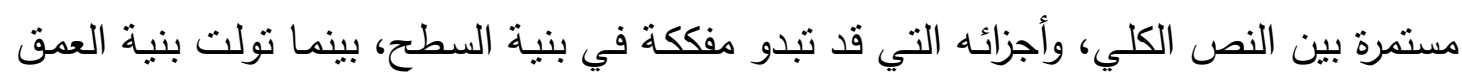
في صنع جسور بين الجزء والكل؛ لينساند الحبك؛ مع السبك؛ ليتحول النص إلى كلٍ منرابطٍ متماسلكٍ لفظًاً ومعنىئٌ شكلًا ومضمونًا.

د9 - - الوزير أبو بكر عاصم بن أيوب البطليوسي، شرح ديوان امرئ القيس، دار الكتب السلطانية، القاهرة،

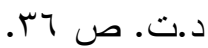




\section{نتائج البحث}

1- أهمية المنظور اللغوي في نقد النص. r- تحققت معظم وسائل السبك في المعلقة. r- حقق التكرار والتضام والحذف السبكَ على مستوى البيت، والمقطع، بينما حقق التعريف والتنكير ، والإحالة والربط السبكَ على مستوى النص.

ع - تساوقت بنية السطح مع بنية العمق في تحقيق تماسك النص وترابطه.

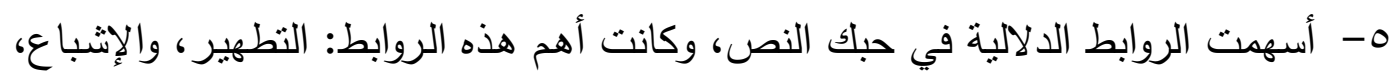
ومثكلة الموت، والأنا الثاعرة.

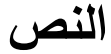

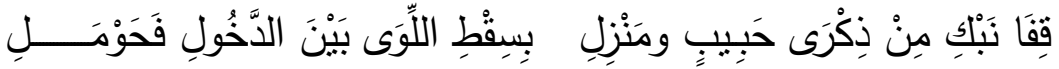

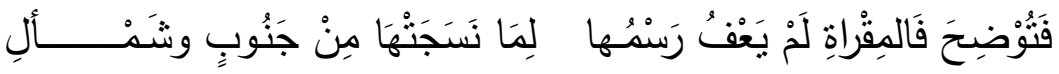

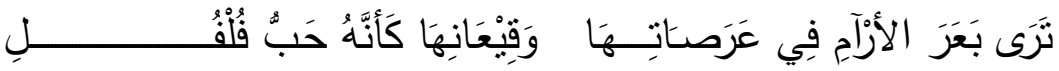

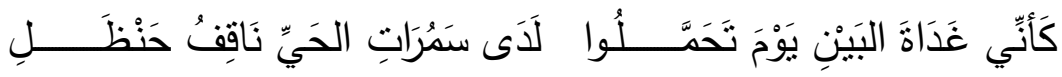

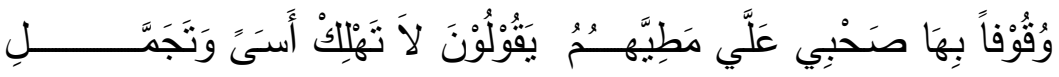

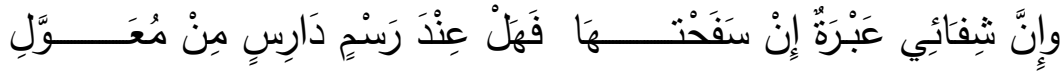

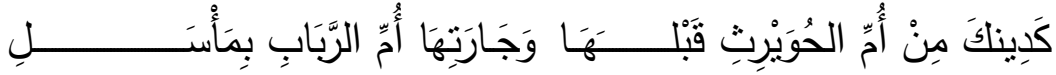

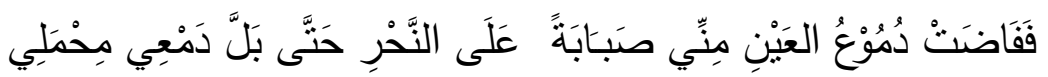

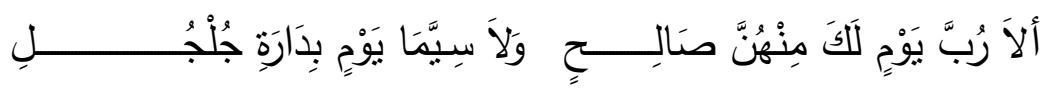

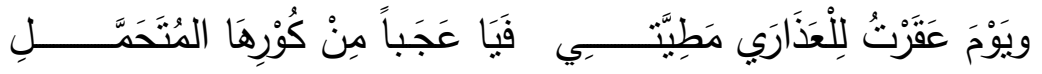

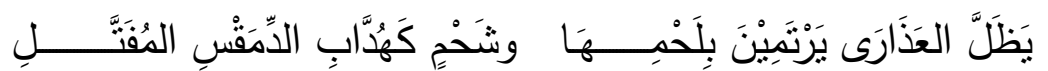

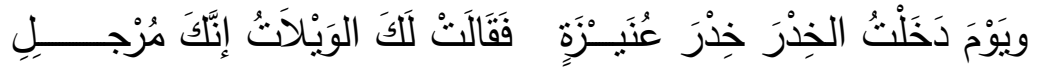

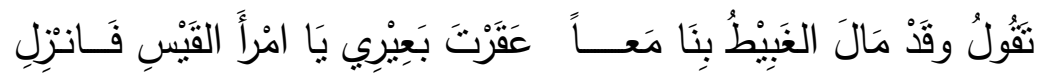

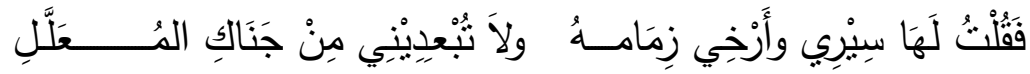

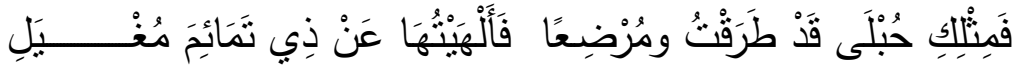

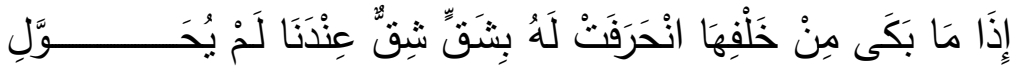

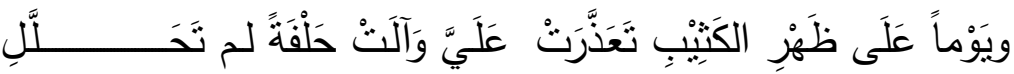

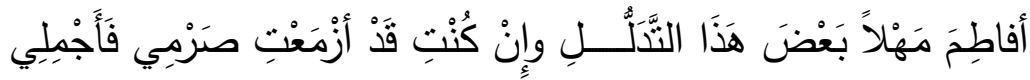

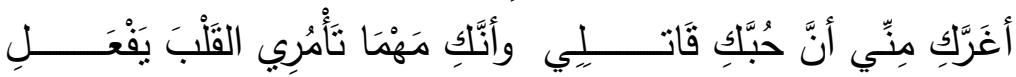




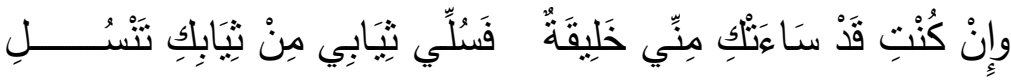

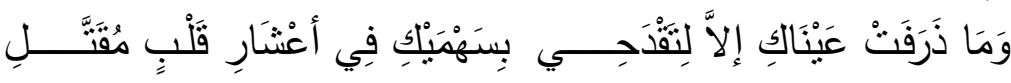

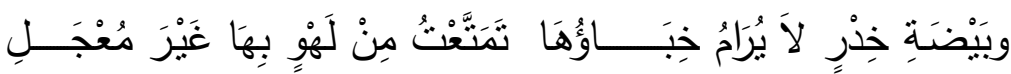

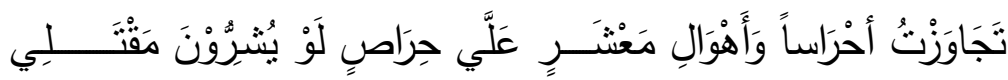

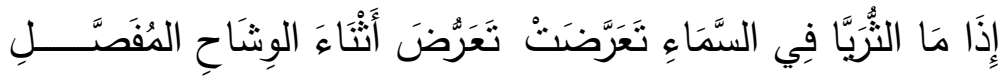

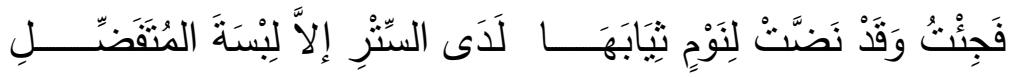

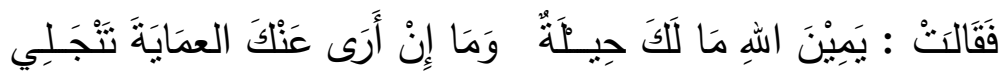

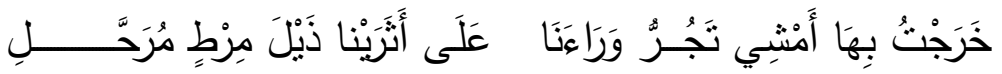

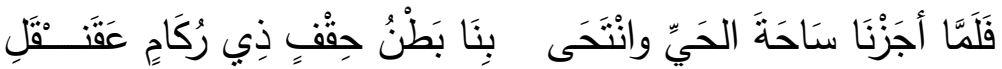

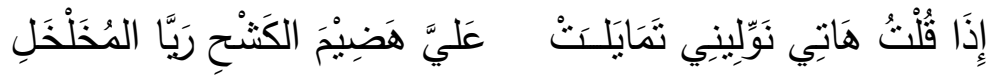

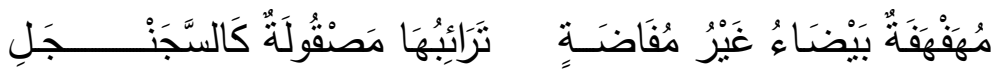

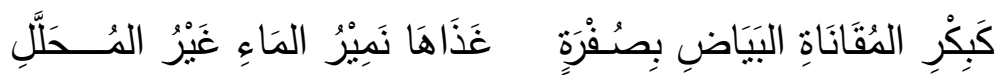

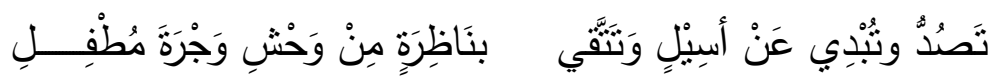

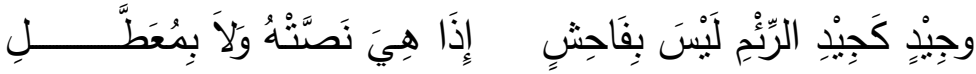

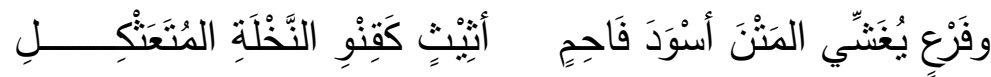

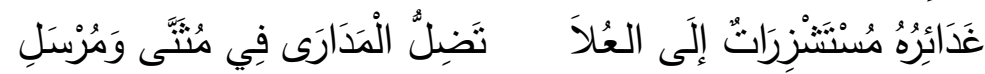

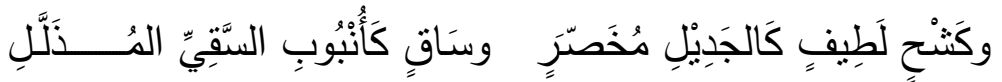

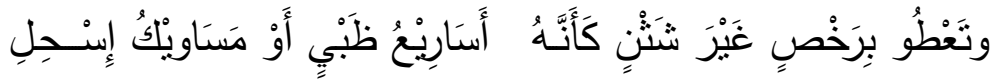

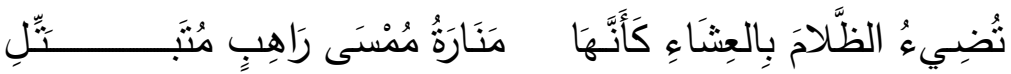

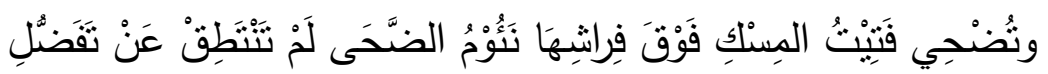

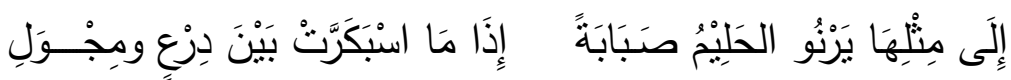

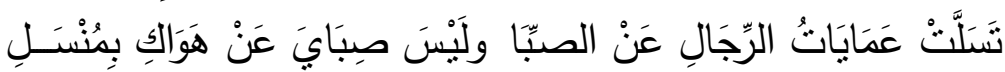

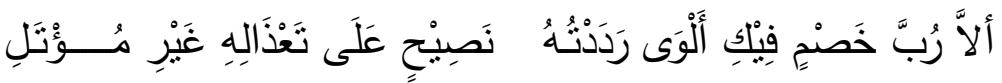

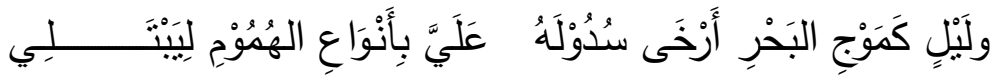

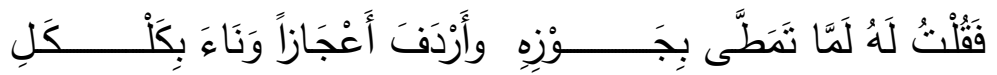

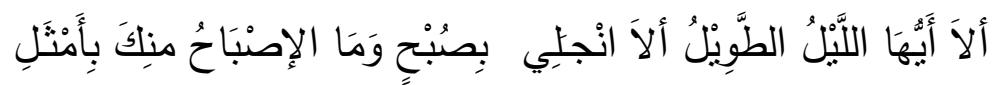

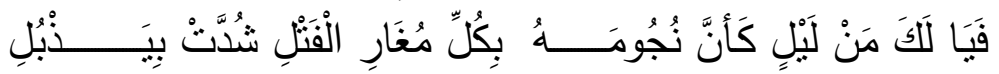

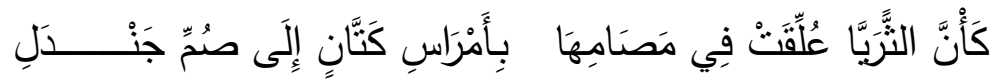

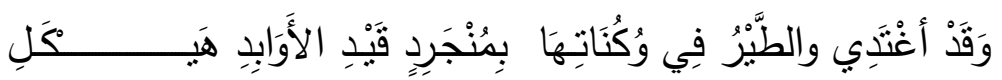




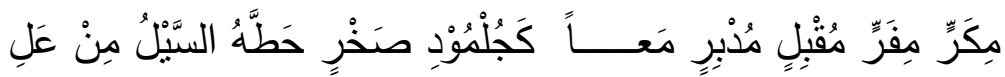

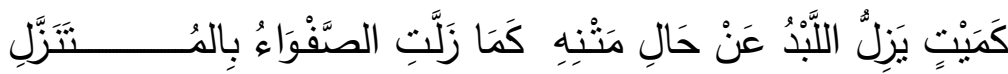

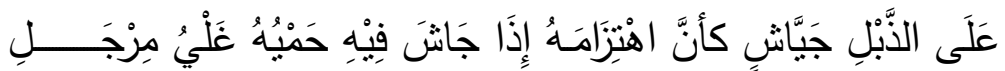

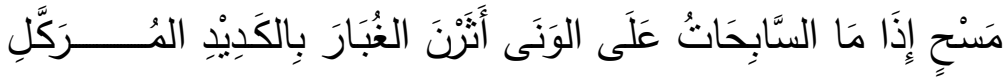

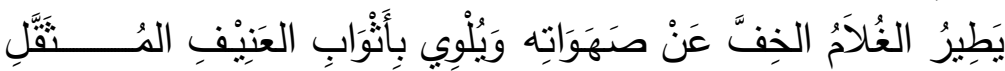

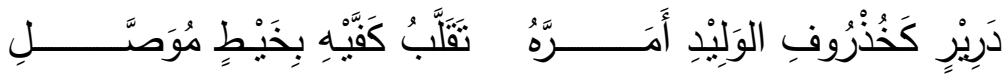

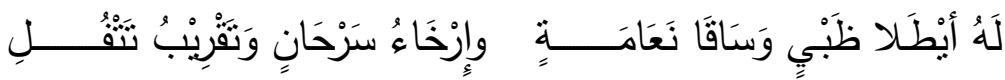

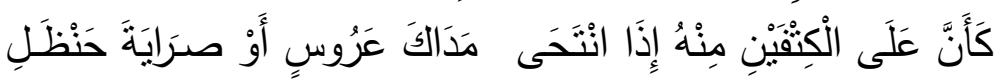

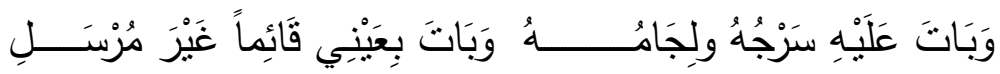

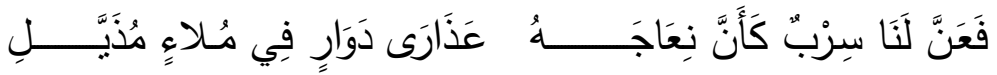

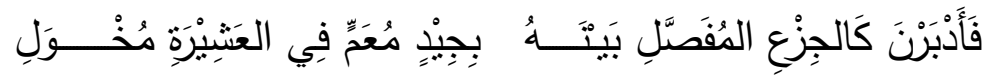

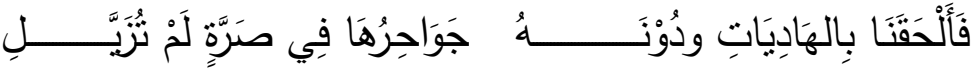

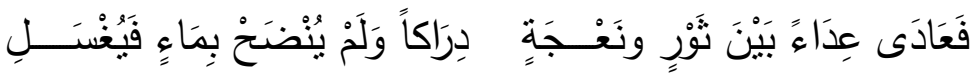

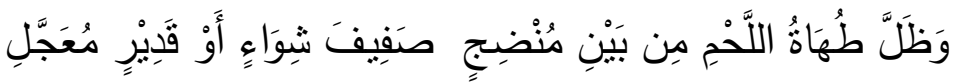

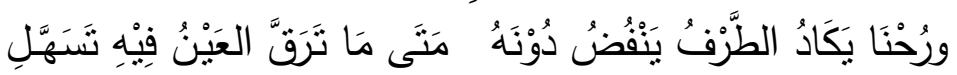

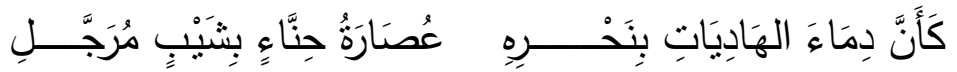

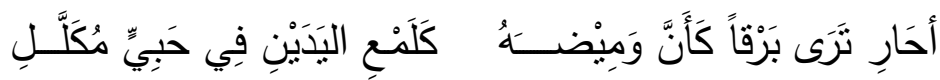

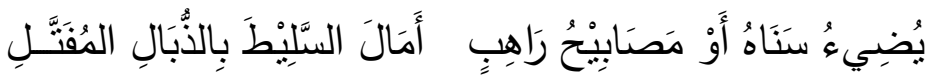

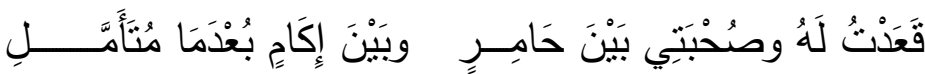

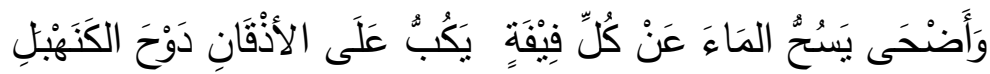

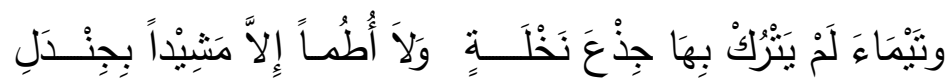

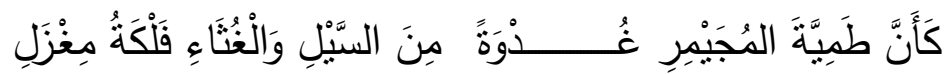

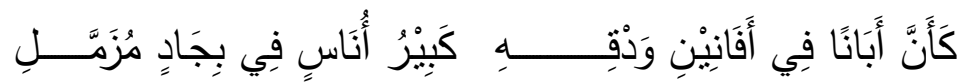

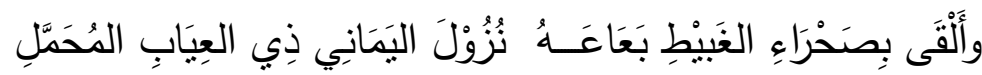

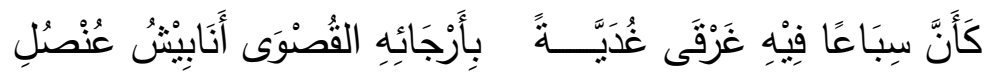

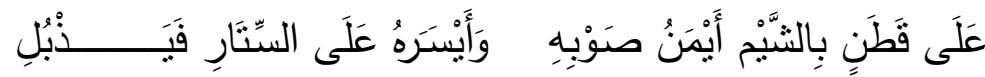

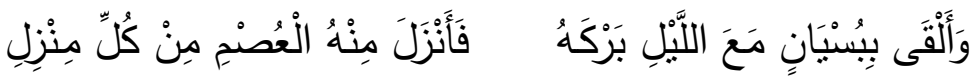




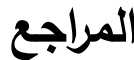

1- أحدد إبراهيم موسى، الصبغ البديعي في اللغة العربية، دار الكاتب العربي للطباعة

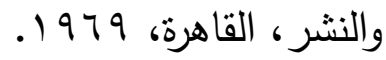

r- أحمد عفيفي، الإحالة في نحو النص دراسـة في الدلالـة والوظيفة، ضدمن كتاب مؤتمر كلية دار العلوم " العربية بين نحو الجملة ونحو النص"، هـ ـ. ـ.

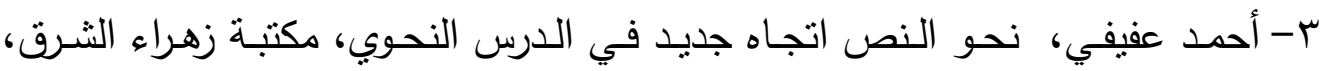

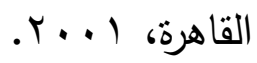

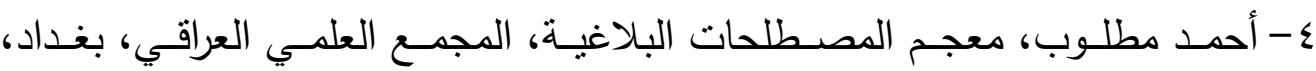
$.191 \mathrm{r}$ ه- الأزهر الزناد، نسيج النص بحث فيما يكون به الملفوظ نصئًا، طا، المركز الثقافي، .1994 צ- إسماعيل بن يونس النحاس، شرح القصائد النسع المشهورات، تحقيق: أحمد خطاب،

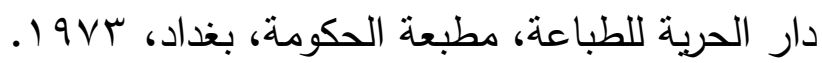
V- أنثرف عبد البديع، الدرس النحوي النصي في كتب إعجاز القرآن، مكتبة الآداب،

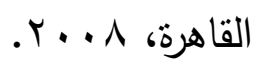
^- امرؤ القيس، ديوانه، تحقيق: محمد أبو الفضل إبراهيم، طه، دار المعارف، القاهرة،

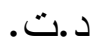
9- الوزير أبو بكر عاصم بن أيوب البطليوسي، شرح ديوان امرئ القيس، دار الكتب

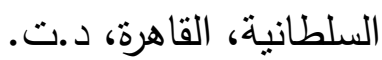
• 1- أبو بكر محمد بن القاسم الأنباري، شرح القصـائد السبع الطوال الجاهليات، تحقيق: عبد السلام محمد هارون، طء، دار المعارف، القاهرة، .91 19.

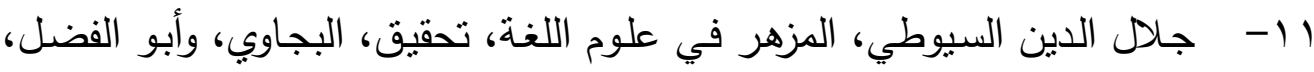
وجاد المولي، دار الكتب العربية، القاهرة، 1910.

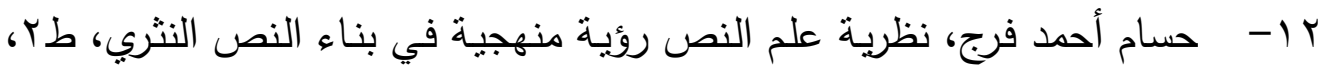

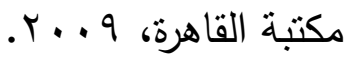

r ا- الحسين بن أحمد بن الحسين الزوزني، شرح المعلقات السبع، تحقيق: محدد

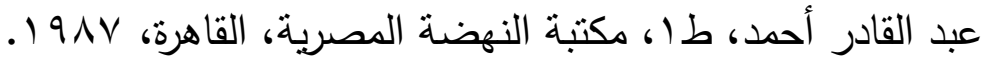

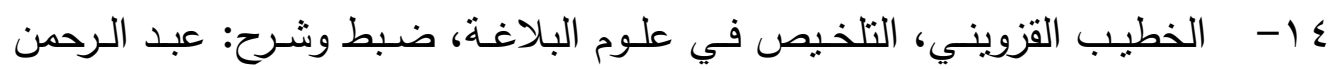

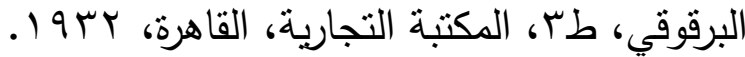


10- رجاء عيد، في البلاغة العربية، مؤسسة كليوباترا، القاهرة، د. ت .

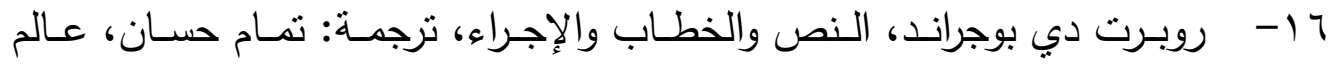

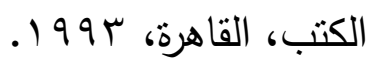

IV - I سعد مصلوح، العربية من نحو الجملة إلى نحو النص، الكتاب التذكاري لقسم اللغة العربية، جامعة الكويت، عبد السلام هارون معلمًا ومؤلفًا ومحققًا، ـ 199 .

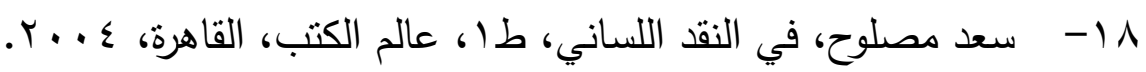

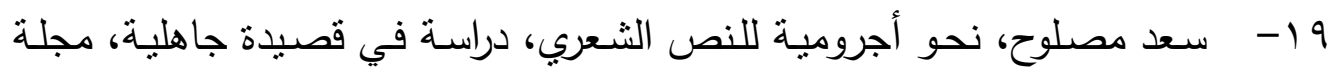

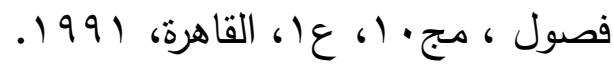

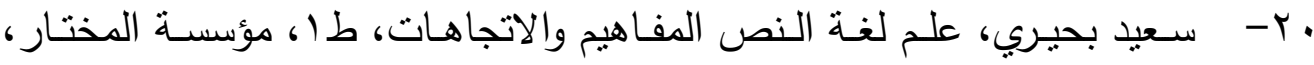

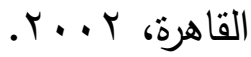
ا r- صبحي إبراهيم الفقي، علم اللغة النصي بين النظرية والنطبيق، طا، دار قباء،

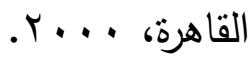

r r- صلاح فضل، بلاغة الخطاب وعلم النص، عالم المعرفة، الكويت، ب99 19.

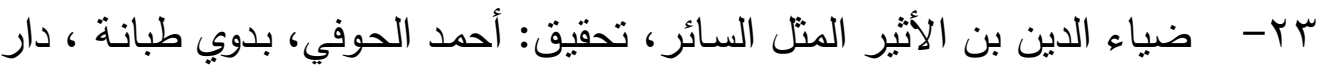
نهضة مصر ، القاهرة.

؟ ץ- عبد الرشيد الصـادق، غربـة الملك الضليل، مجلة فصول، المجلد ع، العدد ؟،

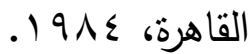

هץ- عبد القاهر الجرجاني، دلائل الإعجـاز، تحقيق: محمود محمد شـاكر، طس،

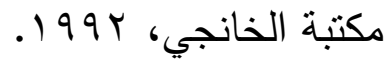

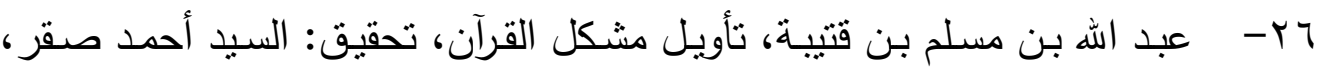

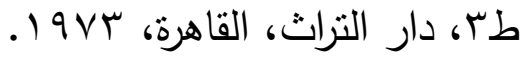
V أبو عثمان عمرو بن بحر الجاحظ، البيان والتبين، تحقيق: عبد السلام هارون، طV، مكتبة الخانجي، القاهرة، 1991.

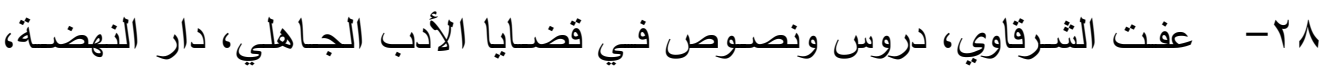

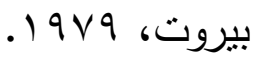

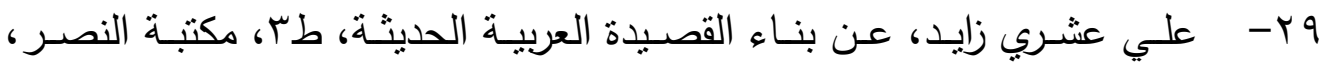
القاهرة، 199 19. •r- - عمر أبو خرمـة، نحو النص نقد النظريـة وبنـاء أخرى، عـالم الكتب، الأردن، $. r . . \Sigma$ 
اس- فولفجانج هاينه مان، ديتر فيهفجر، مدخل إلى علم لغة النص، نرجمة: سعيد

$$
\text { بحيرى، مكتبة زهراء الثرق، القاهرة، ع . . ب. }
$$

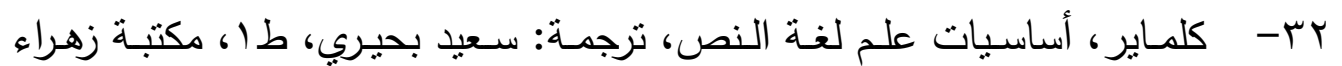

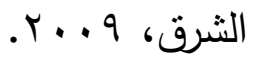

سب- ليندة قياس، لسـيات النص النظرية والتطبيق مقامـات الهمذاني نموذجًا، طا ،

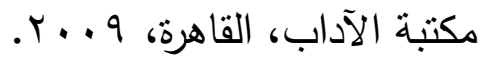

ع ب- ليندة قياس، لسـانيات النص النظريسة والتطبيق مقامات الهمذاني نموذجًا، طاء،

$$
\text { مكتبة الآداب، القاهرة، } 9 \text {. . . ب. }
$$

هب- محمد خطـابي، لسـانيات النص " مدخل إلى انسجام الخطـاب"، ط اه المركز

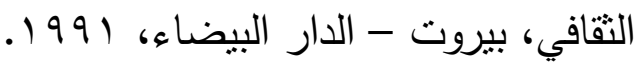

جس- محمد العبد، إبداع الدلالة في الثـعر الجاهلي مدخل لغوي أسلوبي، طاه، دار

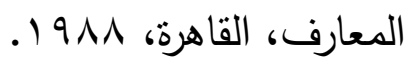

V- - محمد الهادي الطرابلسي النص الأدبي وقضياه عند ميثـال ريفتار من خـل كتاب "صناعة النص" وجون كوهن من خلال كتابه "الكلام السامي" : مجلة فصول

$$
\text { . }
$$

^ץ- محمـود فهمي حجـازي، علم اللغـة بـين التراث والمنـاهج الحديثة، دار غربـ،

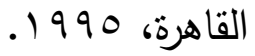

qץ- مصطفى ناصف، دارسة الأدب العربي، الدار القومية للطباعة والنشر ، القاهرة، 